S

\title{
Low-Level Burial Grounds Waste Analysis Plan
}

Prepared for the U.S. Department of Energy Assistant Secretary for Environmental Management

Project Hanford Management Contractor for the

U.S. Department of Energy under Contract DE-AC06-96RL.13200

Fiuor Hanford

P.0. Box 1000

Richland, Washington

RECORD COPY 


\section{ENGINEERING CHANGE NOTICE}

Pine 1 of 2 2 Proj.

\begin{tabular}{|c|c|c|c|c|c|}
\hline $\begin{array}{l}\text { 2. ECN Category (mark one) } \\
\text { suppiemental }\end{array}$ & $\begin{array}{l}\text { 3. Originator's Name, O } \\
\text { M. D. Ellefson/ } \\
\text { Serviccs/T } 3-0.5 /\end{array}$ & $\begin{array}{l}\text { ization, } M S I N \text { and Telepho } \\
\text { nerator } \\
2-0733\end{array}$ & & $\begin{array}{l}\text { ISQ Required? } \\
\text { Yes ONo }\end{array}$ & $\begin{array}{l}\text { 5. Date } \\
\text { Eebruary 29, } 2000\end{array}$ \\
\hline $\begin{array}{l}\text { Change ECN } \\
\text { Temporary }\end{array}$ & $\begin{array}{l}\text { 6. Project Title/No.Mvorl } \\
101607 / \text { /AJ } 60\end{array}$ & der No. & $\begin{array}{l}\text { 7. Bldg./Sys } / F \\
\text { LLEG }\end{array}$ & c. No. & $\begin{array}{l}\text { 8. Approval Designator } \\
\mathrm{EQ}\end{array}$ \\
\hline $\begin{array}{l}\text { Standby } \\
\text { Supersedure } \\
\text { CancelNoid }\end{array}$ & $\begin{array}{l}\text { 9. Document Numbers } \\
\text { sheet no. and rev.) } \\
\text { ENE-SD-EN-WAP-C }\end{array}$ & $\begin{array}{l}\text { iged by this ECN (includes } \\
\text { Rev. } 2\end{array}$ & $\begin{array}{l}\text { 10. Related E } \\
\text { NA }\end{array}$ & $\mathrm{No}(\mathrm{s})$. & $\begin{array}{l}\text { 11. Rolated PONO. } \\
\text { NA }\end{array}$ \\
\hline $\begin{array}{l}\text { 12a. Modification Work } \\
\text { Yes (fill out Blk. 12b) } \\
\text { No (NA Blks. 12b, } \\
12 c, 12 d)\end{array}$ & $\begin{array}{l}\text { 12b. Work Package No. } \\
\text { NA }\end{array}$ & $\begin{array}{l}\text { 12c. Modification Work Co } \\
\text { NA } \\
\text { Oesign Awthorily/Cog, En }\end{array}$ & oted & $\begin{array}{l}\text { 12d. Restore } \\
\text { or Stand } \\
\text { NA. } \\
\text { Design Auth }\end{array}$ & $\begin{array}{l}\text { to Original Condition (Temp. } \\
\text { y ECNs only) } \\
\text { lyy/Cog Engineer Signature \& } \\
\text { Date }\end{array}$ \\
\hline
\end{tabular}

13a. Description of Change

13b. Design Baseline Document? $O$ Yes $O$ No

This ECN cancels HNE-SD-EN-WAP-0O2.

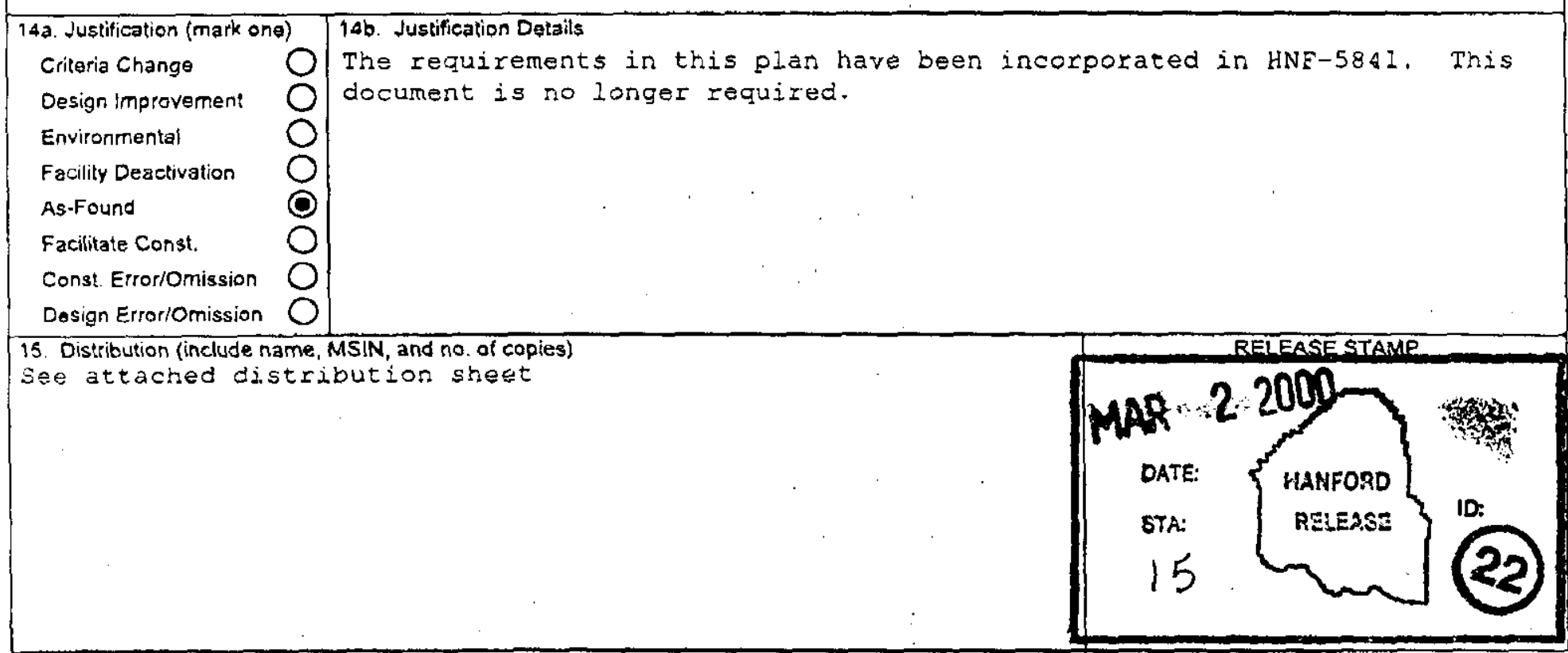




\section{ENGINEERING CHANGE NOTICE}

16. Design Verification Required

OYes

ONo
17. Cost Impact

ENGINEERING

Adqitional $O \$ N A$

Savings $\bigcirc \$ N A$
Page 2 of 2 CONSTRUCTION

Additional

$\$ N A$

Savings
O

$\$ N A$
1. ECN (use no. from pg. 1)

635189

18. Schedule Impact (days) Improvement

NI

Delay $\mathrm{NA}$

19. Change Impact Review: Indicate the related documents (other than the engineering documents identified on Side 1) that will be affected by the change described in Block 13 . Enter the affected doeument number in slock 20.

SDO/DD

Functional Design Criteria

Operating Specification

Criticality Specification

Conceptual Design Report

Equiprnent Spec.

Consi. Spec.

Procurement Spec.

Venofor Information

OM Manual

FSARISAR

Safety Equipment List

Radiation Work Permit

$\square$

$\square$

$\square$

$\square$

$\square$

$\square$

$\square$

$\square$

$\square$

$\square$

$\square$

$\square$

Environmental Impact Statement

Environmental Report

Environmenta! Pormit
Seismic/Stress Analysis

StressiDesign Report

Interfate Control Drawing

Calibration Procedure

Installation Procedure

Maintenanco Procedure

Engineêring Procedure

Operating Instruction

Operating Procedure

Operational Safely Requirement

IEFD Drawing

Cell Arrangement Drawing

Eseential Material Specification

Fac. Proc. Samp. Sehedule

Inspection Plan

Inventory Adjustment Request

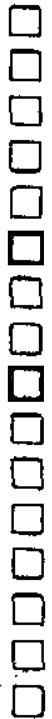

Tank Calibration Manual Health Physics Procedure Spares Multiple Unit Listing Test Procedures/Specification Component Index

ASME Coded Item

Human Factor Consideration

Computer Software.

Electric Circuit Schedule ICRS Procedure

Process Control ManuavPlan

Process Flow Chan

Purchase Requisition

Tickler File

NA

20. Other Affected Documents: (NOTE: Documents listed below will not be revised by this ECN.) Signatures below indicate that the signing organization has been notified of other affecled documents listed below.

NA.

$$
\text { a., .... }
$$

21. Approvals

Signature

Date

Design Authority

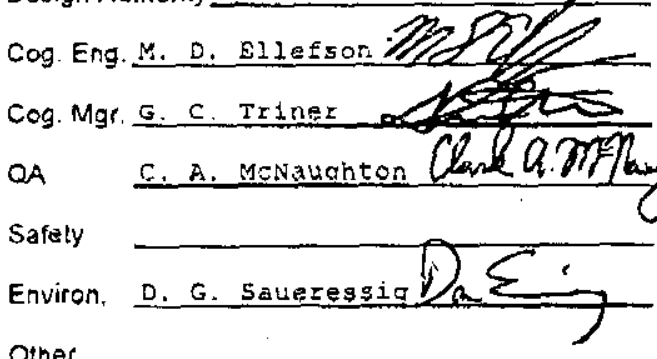

Other
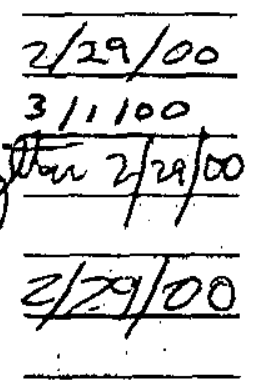

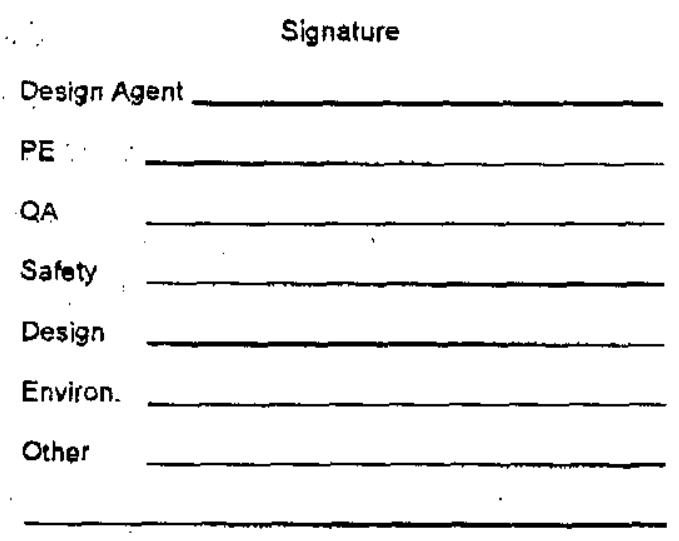

DEPARTMENI OEENERGY

Signature or a Control Number that tracks the Approval Signature

ADDITIONAL

Imo. from Pg.




\section{DISTRIBUTION SHEET}

To

Distribution

Project TitleMork Order

Waste Aralysis Plan for the Low-tevel Burial Grounds

Name

R. E. Bolls

J. B. Buckley, Jr.

D. F. Pratt

i. D. Elletson

C. K. Girres

R. D. Greenwell

J. O. Hanley

C. A. MaNaughton

J. R. Rosser

D. G. Saueressig

G. C. Triner

DPC

From
Waste Services/Generator Services

Date 2/29/2000

EOT NO. NA

ECN No. 635189

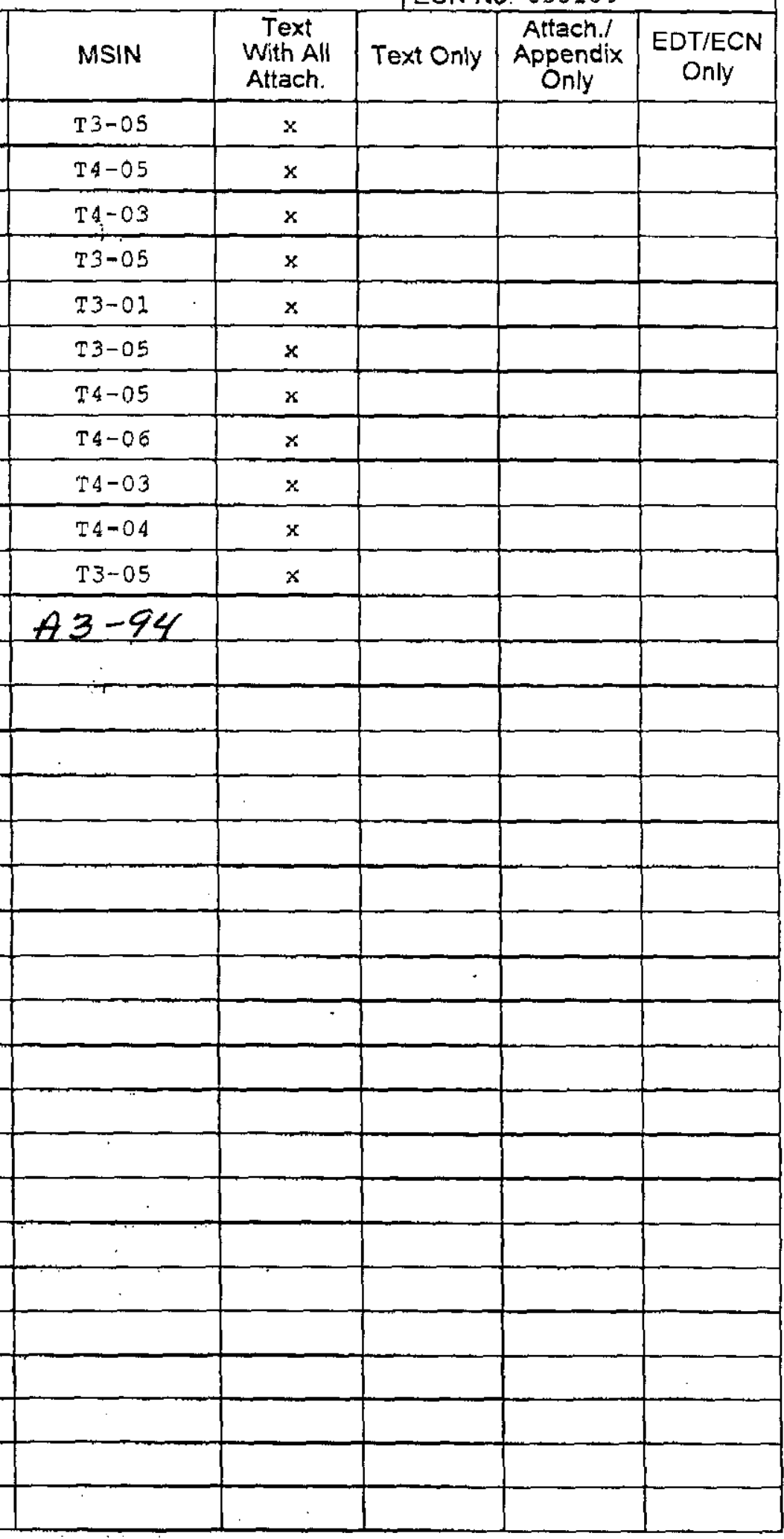




\title{
Waste Analysis Plan for the Low-Level Burial Grounds
}

M. D. Ellefson

Eluor kanford

Richland, WA 99352

U.S. Deparment of Energy Contract DE-ACOS-96RL13200

\author{
EDT/ECN: $635189 \quad$ UC: 2000 \\ Org Code: 33200 Charge Code: 101607AJ60 Hm wm 0021 \\ B\&R Code: EW3130020 Tótal,P,ages: 2.: "...
}

Key Words; Low-level Eurial Grounds, mixed waste, waste acceptance, waste designation, waste characterization, QA/OC, sampling and analysis.

Abstract: This waste analysis plan (WAR) has been prepared for the LowLevel Burial Grounds which are located in the 200 East and West Areas of the Hanford Eacility, Richland, washington. This WAP documents the methods used to characterize, obtain and analyze representative sanples of waste managed at this unit.

Cancelled - The requirements of this WAP are now in HNF-5841-0.

TRADEMARK DISCLAIMER. Reference herein to any specific commercial product, process, or service by trade name, trademark, manufacturer, or otherwise, does not necessarily constitute or imply its endorsement, recommendation, or favoring by the United States Government or any agency thereof or its contractors or subcontractors.

Printed in the United States of America. To obtain copies of this document, contact: Document Control Servlces, P.O. Box 950. Mailstop H6-08, Richland WA 99352, Phone (509) 372-2420; Fax (509) 376-4989.

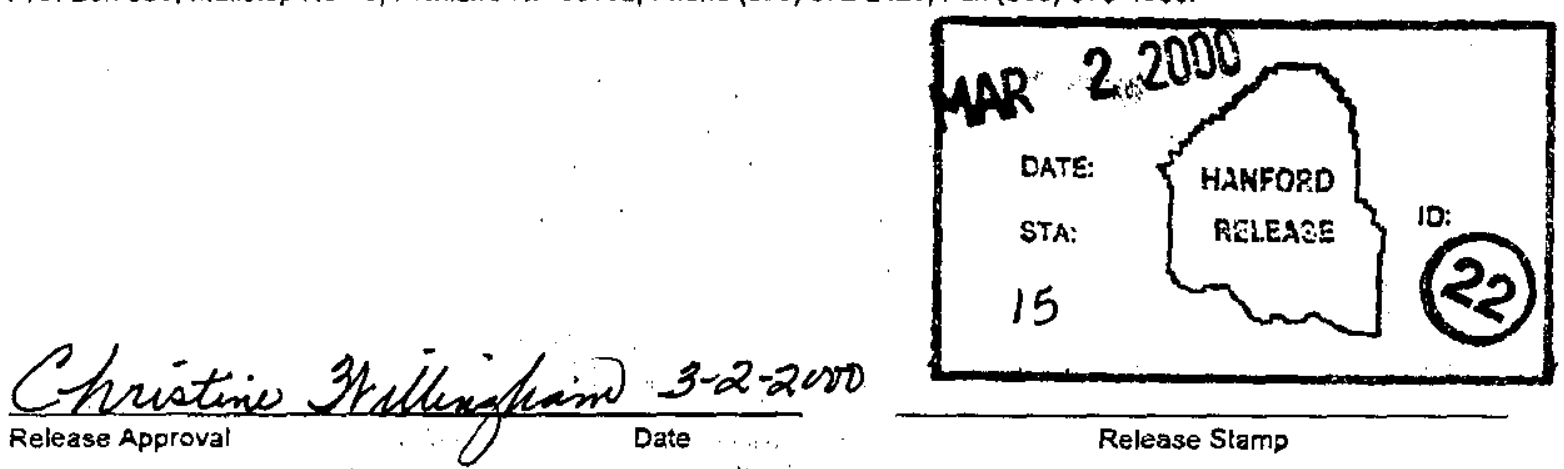

Approved For Public Release 


\section{RECORD OF REVISION}

(2) Title

Waste Analysis Plan for the Low-Level Burial Grounds

Change Control Record

(3) Revision

(4) Description of Change - Replace, Add, and Delete Pages

\begin{tabular}{|l|l}
\hline 0 & $\begin{array}{l}(7) \\
\text { EOT }-161194, \text { dated } 2 / 13 / 96 .\end{array}$ \\
\hline 1 & Incorporated changes per ECN\#630806. \\
\hline 2 & Incorporated changes per ECN\# 639100. \\
\hline 3 RS & Cancels HNE-SD-EN-WAP-002 per ECN\# 635189.
\end{tabular}

Authorized for Release

\begin{tabular}{l|ll} 
(5) Cog. Engr. & (6) Cog. Mgr. Date
\end{tabular}

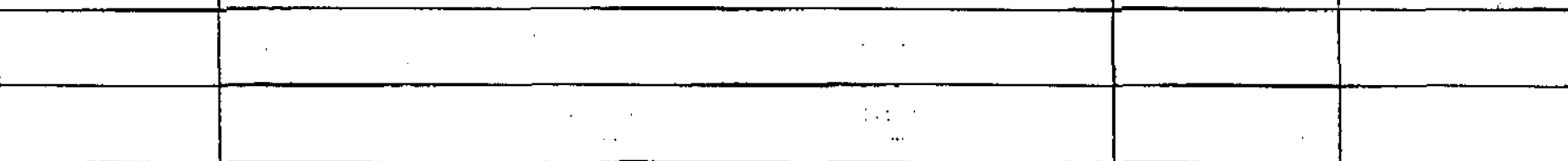




\section{RECORD OF REVISION}

(2) Titie

Waste Analysis Plan for the Low-level. Burial Grounds

Change Control Record

(3) Revision

(4) Description of Change - Replace, Add, and Delete Pages

\begin{tabular}{|c|l}
\hline 0 & $\begin{array}{l}(7) \\
\text { EDT }-161194, \text { dated 2/13/96. }\end{array}$ \\
\hline 1 & Tncorporated changes per ECN\# 630806. \\
\hline 2 & Incorporated changes per ECN\# 639100. \\
\hline 3 RS & Carcels HNE-SD-EN-WAP-002 per ECN\#635189.
\end{tabular}

Authorized for Release

\begin{tabular}{l|l} 
(5) Cog. Engr. & (6) Cog. Mgr.
\end{tabular} Date

M.D.

Ellefson 7 or prestur encerex 28
Acgneture see prege 27 ECO

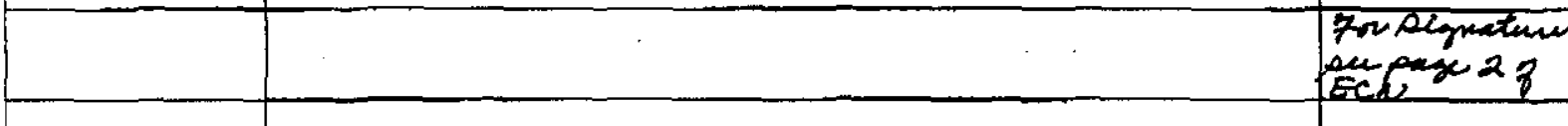




\section{RELEASE AUTHORIZATION}

Document HNF-5841, Rev. 0

Number:

Document Title: Low-Level Burial Grounds Waste Analysis Plan

This document, reviewed in accordance with DOE Order 241.1, "Scientific and Technical Information Management," and DOE G 241.1-1, "Guide to the Management of Scientific and Technical Information," does not contain classified or sensitive unclassified information and is:

\section{APPROVED FOR PUBLIC RELEASE}

\section{Chistros Shillenigh am \\ C. Willingham \\ Lockheed Martin Services, Inc. \\ Document Control//nformation Clearance}

Reviewed for Appled Technobgy, Business Sensitive, Classified, Copyrighted, Export Controled, Patent, PersonalPrivate, Proprietery, Protected CRADA, Tradernerk, Unclassified Controllod Nucber inlormation.

LEGAL DISQAIMER. This report was prepered as en account of work sponsored by en agency of the United States Government. Neither the United Sletes Government nor eny agency thereof, not any of their employees, nor any of their contractors, subcontractors or their omployeos, mekes any warrenty, express or impted, or assumes any bgal iabilty or responsibility for the accuracy, completeness, or eny third partys use or the results of such use of any information, epperatus, product, or process discbsed, or represents that its use would not infringe privately ouned rights. Relerence herein to any specific commercial product, process, or service by trade name, trademerk. manufacturer, or otherwise, does not necessarily constitute or imply its endorsement, recommendation, or favoring by the United States Government or any sgency thereof or its contractors or subcontractors. The views and opinions of authors expressed herein do not recesseriy state or reflect those of the United States Government or any agency thereol. This report has been reproduced from the best avaibble copy. Printed in the United States of Anerica. 


\section{INFORMATION CLEARANCE FORM}

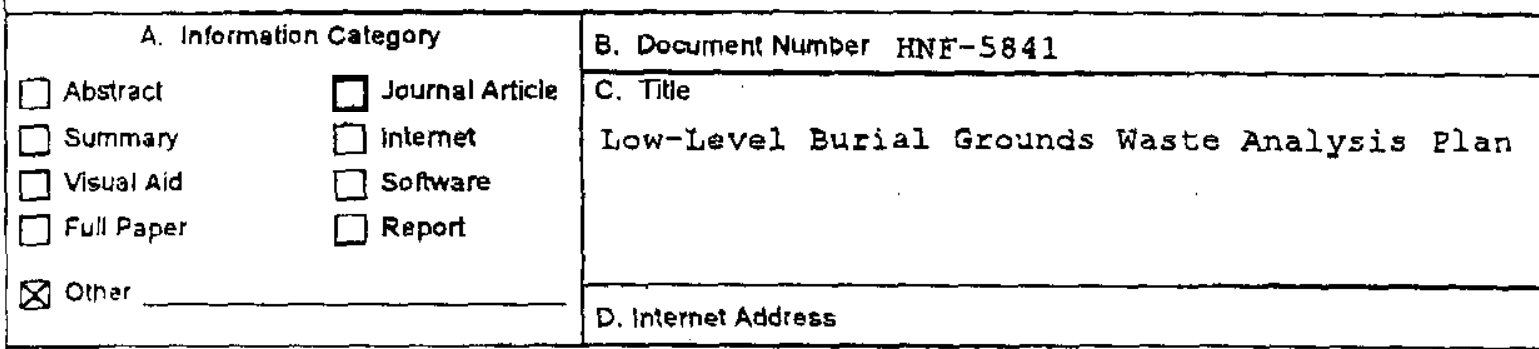

E. Required Information

1. Is document patentially Classifled? $\mathrm{O}$ No

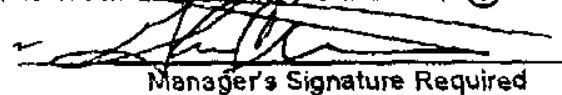

Manager's Signature Required

If Yes

ADC Signsture Required

2. Internal Review Regulred?

if Yes, Document Signatures Below

OYes (MANDATORY)

$\left.\right|^{4 .}$

a. Naw or Noval (Patentable) subjoca Mattar? ONo OYas

If "Yos", Disclosure No:

b. Information Received in Confidence, such as Proprietry and/or inventions? ONo OYes "If "Yes". Affix Appropriate Legends/Notleos.

c. copyrights? ONo OYes if "Yos", Atach Pormission.
a. Trademarks? ONo OYes if "Yes", Identify in Document.

5. Is Information requiring submission to OSTh $\odot$ No $\bigcirc$ Yes

if Yes $U C$ and $B \& R-$

6. Relesse Levein $O$ Publit $O$ Limlied

7. charge code $10 / 598 / 0420$

F. Complete for a Journal Aricle

1. Title of Journal

\section{G. Complele for a Presentation}

1. Titte for Conference or Meeting

2. Group Sponsoring

3. Date of Conference

5. Will Information be Published in Proceedings? $O$ No $O$ Yes

H. Author/Requestor

(Print and Slgn)

1. Reviewers Yes Print Signature

5. Will Material be Handed Out? $O$ No $O$ Yes

Responsible Manager

General Counsel

$\square$

Office of External Affairs

DOE-RL

other- Lms 2

D

C. NiLlingham (Print and Sign)

Publlc Y/N (II N, complete J)

Other

$\square$ C.m

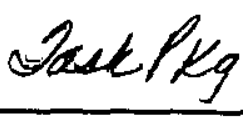

$$
\begin{aligned}
& Y / N \\
& Y / N \\
& Y / N \\
& Y / N \\
& Y / N
\end{aligned}
$$

5. If information Includes Sensitive information and is not to be isleased to the Public indicate category below.
$\square$ Applięd Technology
$\square$ Personal/Private
$\square$ Protected CRADA
$\square$ Proprietary
$\square$ Export Contralled
$\square$ Business-Sensitive
$\square$ Procurement-Sensitive
$\square$ Predecisional
$\square$ Patentable
Other (Specify)

$\square$ Predecis
$\square$ UCN!

K. If Additional Comments, Please Attach Separate Shed 


\section{Low-Level Burial Grounds Waste Analysis Plan}

Date Published

March 2000

Prepared for the U.S. Department of Energy

Assistant Secretary for Environmental Management

\section{Fluor Hanford}




\section{RELEASE AUTHORIZATION}

Document HNF-5841

Number:

Document Title: Low-Level Burial Grounds Waste Analysis Plan

This document, reviewed in accordance with DOE Order 241.1, "Scientific and Technical Information Management," and DOE G 241.1-1, "Guide to the Management of Scientific and Technical Information," does not contain classified or sensitive unclassified information and is:

\section{APPROVED FOR PUBLIC RELEASE}

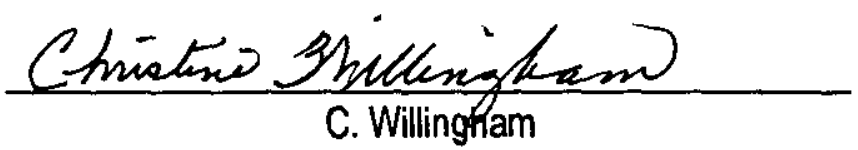

C. Willingham

Lockheed Martin Services, Inc.

Document Control//nformation Clearance

Reviewed for Appled Technobgy, Business Sensitive, Clessified, Copyrighted, Espont Controlod, Patent, Personalprivale, Proprietery. Protected CRADA, Trademark, Unclassified Controlad Nucber information.

LEGAL DISCLAIMER. This report was prepered as en eccount of work sponsored by an egency of the Uhited Stales Government. Noither the United Stetes Government nor eny egency thereol, not any of their empbyees, nor eny of their contrectors. subcontractors or their empbyees, mekes any werrenty, express or impled, or essumes any bgal febiity or responsibiity for the eccuracy, completeness, or any third party's use or the results of such use of eny information, epperetus, product, or process discbesd, or represents that its use would not infringe privately owned rights. Reference herein bo any specific commercial product, process, or service by trade name, trademenk, manufacturer, or otherwise, does not necesserily constitute or imply its endonsement, recommendation, or fenoting by the Uhited States Govemment or eny agency thereof or its contractors or subcontractors. The vews and opinions of authors expressed herein do not necessarily state or refbet those of the United States Govemment $\alpha x$ any agency thereof. This report has been reproduced from the best avaibable copy. Pinted in the Uhiled Stales of America. 


\section{CONTENTS}

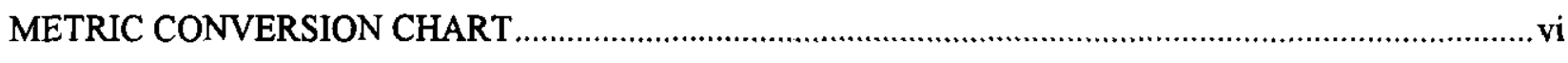

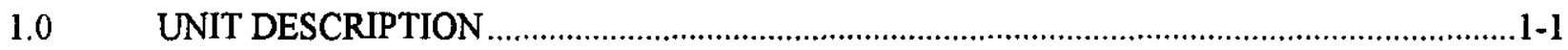

1.1 DESCRIPTION OF PROCESSES AND ACTIVITIES …............................................... $1-1$

1.1.1 How Waste is Accepted, Moved, Processed, and Managed ......................................................1-2

1.1.1.1 Narrative Process Descriptions ........................................................................................

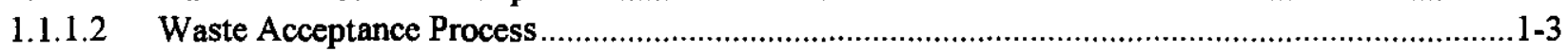

1.1.1.3 Description of Performance Evaluation System ................................................................

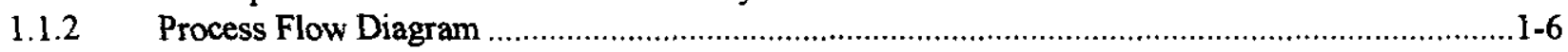

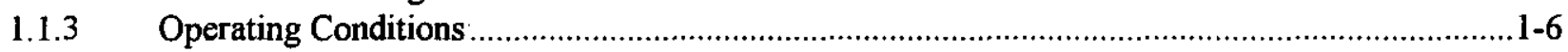

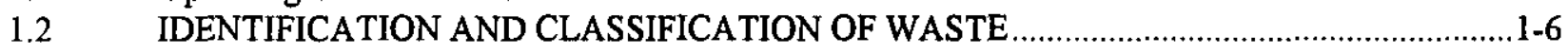

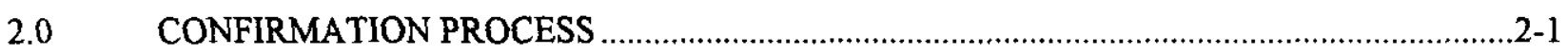

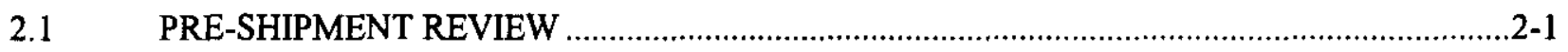

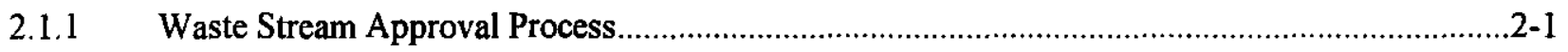

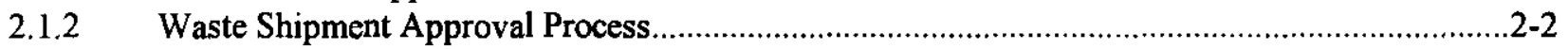

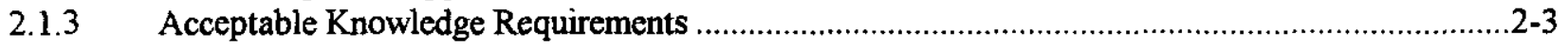

2.1.3.1 General Acceptable Knowledge Requirements.................................................................... $2-3$

2.1:3.2 Methodology to Ensure Compliance with Land Disposal Restrictions Requirements ..................2-4

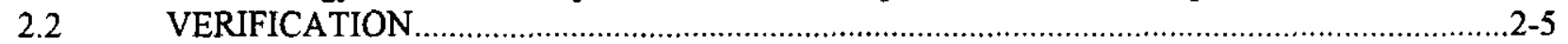

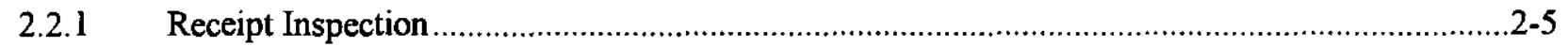

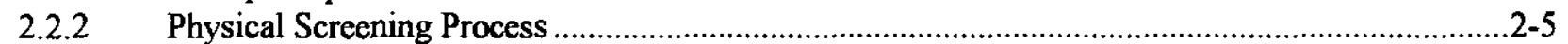

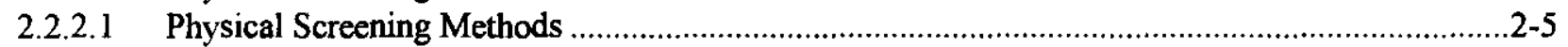

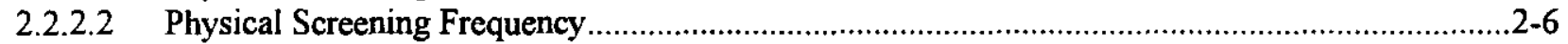

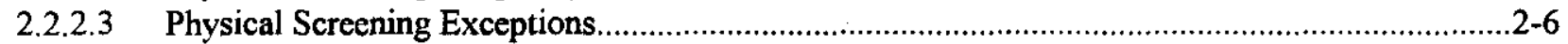

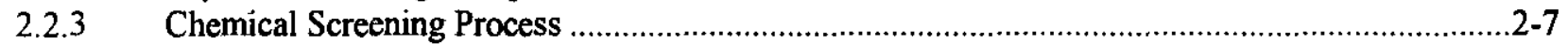

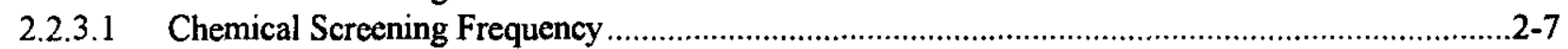

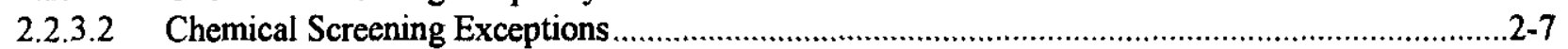

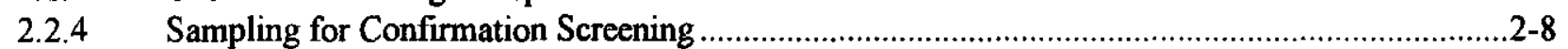

2.2.5 Quality Assurance and Quality Control for Confirmation Process .............................................2-8

2.2.5.1 Physical Screening Quality Control ......................................................................................

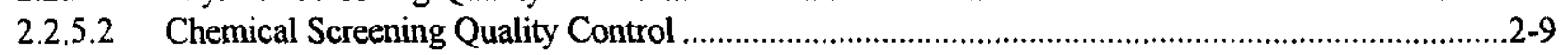

SELECTING WASTE ANALYSIS PARAMETERS ..........................................................

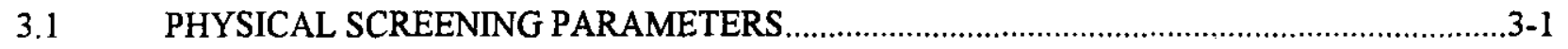

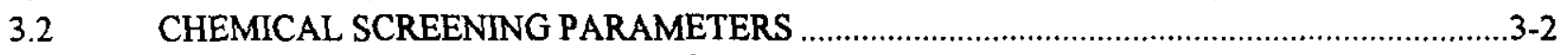

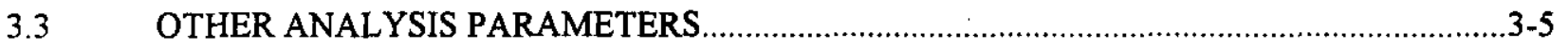

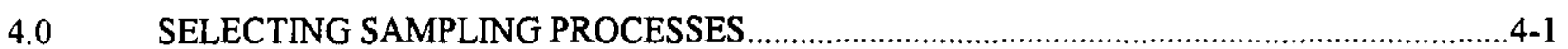

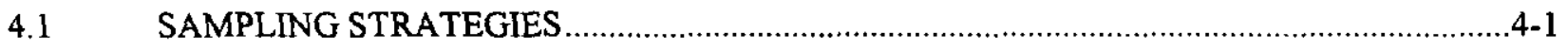

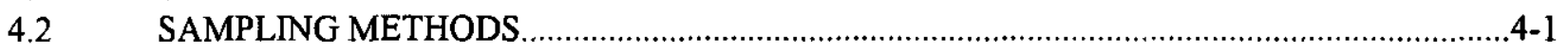

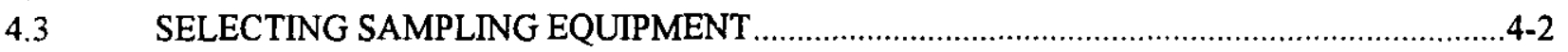

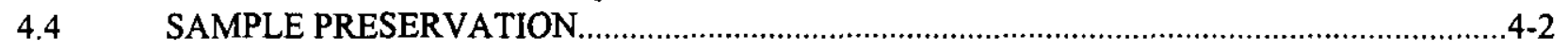

4.5 ESTABLISHING QUALITY ASSURANCE/QUALITY CONTROL PROCEDURES FOR SAMPLING 
HNF-5841

\section{CONTENTS (cont)}

5.0 SAMPLING AND ANALYTICAL PROGRAM

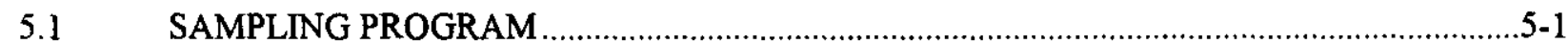

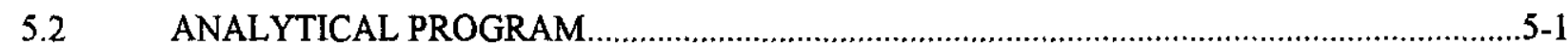

6.0 SELECTING WASTE RE-EVALUATION FREQUENCIES .............................................

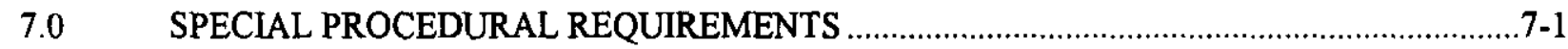

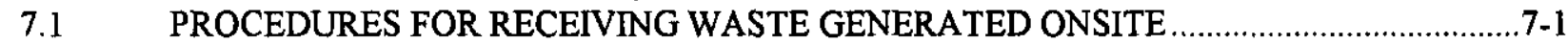

7.2 PROCEDURES FOR RECEIVING WASTE GENERATED OFFSITE ................................ $7-1$

7.3 PROCEDURES FOR IGNITABLE, REACTIVE, AND INCOMPATIBLE WASTE ................7-1

7.4 PROVISIONS FOR COMPLYING WITH FEDERAL AND STATE LAND DISPOSAL RESTRICTION REQUIREMENTS

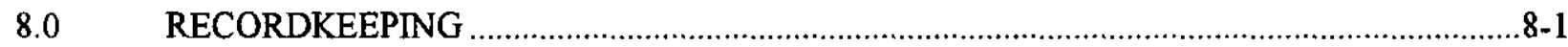

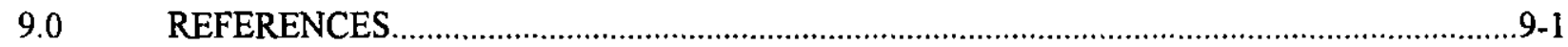

A ANALYTICAL PARAMETERS, METHODS, AND RATIONALE FOR WASTE RECEIVED AT LOW-LEVEL BURIAL GROUNDS APP A-i

Figure 1-1. Locations of Low-Level Burial Grounds in the 200 East Area........................................ F1-1

Figure 1-2. Locations of Low-Level Burial Grounds in the 200 West Area......................................... F1-2

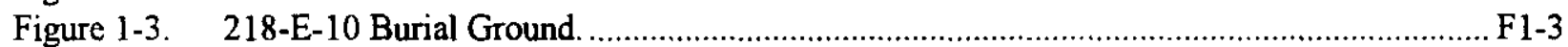

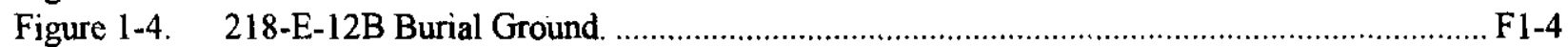

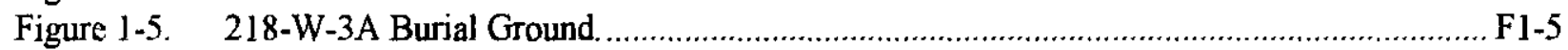

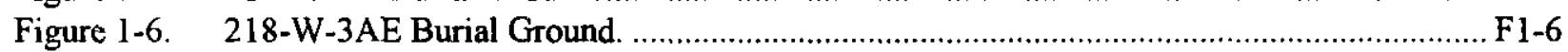

Figure 1-7. 218-W-4B Burial Ground........................................................................................

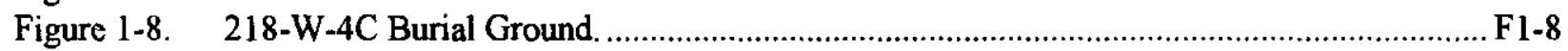

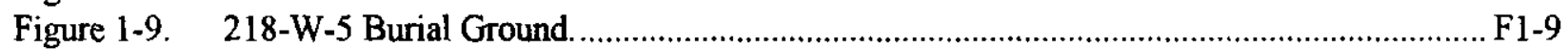

Figure 1-10. Typical Resource Conservation and Recovery Act-Compliant Liner System................... F1-10

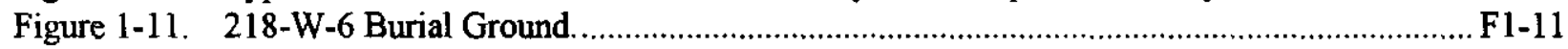

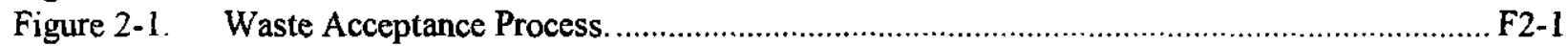

\section{TABLE}

Table 4-1. Low-Level Burial Ground Chemical Screening Sampling Equipment.

T4-1 


\section{GLOSSARY}
ALARA
as low as reasonably achievable
AWMP
alternative waste management plan
CAP
corrective action plan
COLIWASA
composite liquid waste sampler
CFR
CWC
Code of Federal Regulations
Central Waste Complex
DOE-RL
U.S. Department of Energy, Richland Operations Office
Ecology
Washington State Department of Ecology
HNF
Hanford Nuclear Facility (document identifier)
LDR
land disposal restriction
LLBG
Low-Level Burial Grounds
MSDS
material safety data sheet
PCB
polychlorinated biphenyl
PES
$\mathrm{pH}$
performance evaluation system
negative concentration logarithm of the hydrogen-ion concentration
QA/QC
quality assurance and quality control
RCRA
Resource Conservation and Recovery Act of 1976
RCW
Revised Code of Washington
RTR
real-time radiography
SWITS
solid waste information tracking system
SWMU
solid waste management unit
TRU
transuranic
TSD
treatment, storage, and/or disposal
WAC
WAP
WRAP
WSRd
${ }^{\circ} \mathrm{C}$
Washington Administrative Code
waste analysis plan
Waste Receiving and Processing Facility
waste specification record
degrees Celsius 


\section{METRIC CONVERSION CHART}

The following conversion chart is provided to the reader as a tool to aid in conversion.

Into metric units

Out of metric units

\begin{tabular}{|c|c|c|c|c|c|}
\hline If you know & Multiply by & To get & If you know & Multiply by & To get \\
\hline \multicolumn{3}{|c|}{ Length } & \multicolumn{3}{|c|}{ Length } \\
\hline inches & 25.40 & millimeters & millimeters & 0.0393 & inches \\
\hline inches & 2.54 & centimeters & centimeters & 0.393 & inches \\
\hline feet & 0.3048 & meters & meters & 3.2808 & feet \\
\hline yards & 0.914 & meters & meters & 1.09 & yards \\
\hline miles & 1.609 & kilometers & kilometers & 0.62 & miles \\
\hline \multicolumn{3}{|c|}{ Area } & \multicolumn{3}{|c|}{ Area } \\
\hline square inches & 6.4516 & $\begin{array}{l}\text { square } \\
\text { centimeters }\end{array}$ & $\begin{array}{l}\text { square } \\
\text { centimeters }\end{array}$ & 0.155 & square inches \\
\hline square feet & 0.092 & square meters & square meters & 10.7639 & square feet \\
\hline square yards & 0.836 & square meters & square meters & 1.20 & square yards \\
\hline square miles & 2.59 & $\begin{array}{l}\text { square } \\
\text { kilometers }\end{array}$ & $\begin{array}{l}\text { square } \\
\text { kilometers }\end{array}$ & 0.39 & square miles \\
\hline acres & 0.404 & hectares & hectares & 2.471 & acres \\
\hline \multicolumn{3}{|c|}{ Mass (weight) } & \multicolumn{3}{|c|}{ Mass (weight) } \\
\hline ounces & 28.35 & grams & grams & 0.0352 & ounces \\
\hline pounds & 0.453 & kilograms & kilograms & 2.2046 & pounds \\
\hline short ton & 0.907 & metric ton & metric ton & 1.10 & short ton \\
\hline \multicolumn{3}{|c|}{ Volume } & \multicolumn{3}{|c|}{ Volume } \\
\hline fluid ounces & 29.57 & milliliters & milliliters & 0.03 & fluid ounces \\
\hline quarts & 0.95 & liters & liters & 1.057 & quarts \\
\hline gallons & 3.79 & liters & liters & 0.26 & gallons \\
\hline cubic feet & 0.03 & cubic meters & cubic meters & 35.3147 & cubic feet \\
\hline cubic yards & 0.76 & cubic meters & cubic meters & 1.308 & cubic yards \\
\hline \multicolumn{3}{|c|}{ Temperature } & \multicolumn{3}{|c|}{ Temperature } \\
\hline Fahrenheit & $\begin{array}{l}\text { subtract } 32 \\
\text { then multiply } \\
\text { by } 5 / 9 \text { ths }\end{array}$ & Celsius & Celsius & $\begin{array}{l}\text { multiply by } \\
9 / 5 \text { ths, then } \\
\text { add } 32\end{array}$ & Fahrenheit \\
\hline
\end{tabular}

Source: Engineering Unit Conversions, M. R. Lindeburg, PE., Second Ed., 1990, Professional Publications, Inc., Belmont, California. 
The purpose of this waste analysis plan (WAP) is to document the waste acceptance process, sampling methodologies, analytical techniques, and overall processes that are undertaken for waste accepted for storage and/or disposal at the Low-Level Burial Grounds (LLBG), which are located in the 200 East and 200 West Areas of the Hanford Facility, Richland, Washington. Because dangerous waste does not include the source, special nuclear, and by-product material components of mixed waste, radionuclides are not within the scope of this documentation. The information on radionuclides is provided only for general knowledge. The LLBG also receive nondangerous low-level radioactive waste for disposal. The requirements of this WAP are not applicable to this nondangerous low-level waste.

This document has been revised to meet the interim status waste analysis plan requirements of Washington Administrative Code (WAC) 173-303-300(5).

\subsection{DESCRIPTION OF PROCESSES AND ACTIVITIES}

The LLBG are a land-based unit consisting of eight burial grounds located in the 200 East Area and 200 West Area. Seven of the eight burial grounds (218-E-10, 218-E-12B, 218-W-3A, 218-W-3AE, 218-W-4C, 218-W-5, and 218-W-6) are, or will be, used for the disposal of mixed waste and are subject to Dangerous Waste Regulations, Washington Administrative Code (WAC) 173-303. One burial ground (218-W-4B) is designated as a solid waste management unit (SWMU) (Figures 1-1 and 1-2).

The 218-E-10, 218-E-12B, 218-W-3A, 218-W-3AE, 218-W-4C, 218-W-5 and 218-W-6 Burial Grounds are classified as landfills. The regulated portions of the LLBG cover a total area of approximately 49 hectares.

The 218-E-10 and 218-E-12B Burial Grounds are located in the 200 East Area. The 218-W-3A, 218-W-3AE, 218-W-4B, 218-W-4C, 218-W-5, and 218-W-6 Burial Grounds are located in the 200 West Area. The LLBG consist of various sizes and depths of lined and unlined disposal trenches. All mixed waste destined for disposal will meet land disposal restriction (LDR) requirements [WAC 173-303-140 and 40 Code of Federal Regulations (CFR) 268] or other regulatory alternatives. The lined trenches have leachate collection and removal systems. The less-than-90-day leachate collection tanks are operated in accordance with the generator provisions of WAC 173-303-200 and are not subject to this WAP.

Future trench development and configuration within a burial ground are subject to change as disposal techniques improve or as waste management needs dictate. Mixed waste is disposed in lined or in unlined trenches in accordance with applicable LDR requirements. An electronic database, which can be found within the LLBG operating organization, is maintained that documents each waste receipt, type of waste, and disposal location.

- The 218-E-10 Burial Ground (Figure 1-3) is approximately 36.1 hectares in size and began receiving waste in 1960. Examples of waste placed in this burial ground include failed equipment, rags, paper, rubber gloves, disposable supplies, broken tools, and post-August 19, 1987 Resource Conservation and Recovery Act RCRA of 1976 and state-only designated mixed waste.

- The 218-E-12B Burial Ground (Figure 1-4) is approximately 68 hectares in size and began receiving waste in 1967. Examples of waste placed in this burial ground include defueled reactor compartments (trench 94), low-level waste, and retrievable transuranic (TRU) waste. 
- The 218-W-3A Burial Ground (Figure 1-5) is approximately 20.4 hectares in size and began recejving waste in 1970. Examples of waste placed in this burial ground include ion exchange resins, failed equipment, tanks, pumps, ovens, agitators, heaters, hoods, jumpers, vehicles, accessories and post-August 19, 1987 RCRA and state-only designated mixed waste, and retrievable TRU waste.

- The 218-W-3AE Burial Ground (Figure 1-6) is approximately 20 hectares in size and began receiving waste in 1981. Examples of waste placed in this burial ground include rags, paper, rubber gloves, disposable supplies, broken tools, and post-August 19, 1987 RCRA and state-only designated mixed waste.

- The 218-W-4B Burial Ground (Figure 1-7) is approximately 3.5 hectares in size and began receiving waste in 1968. Examples of waste placed in this burial ground include rags, paper, rubber gloves, disposable supplies, broken tools, alpha caissons, and retrievable TRU waste.

- The 218-W-4C Burial Ground (Figure 1-8) is approximately 20 hectares in size and began receiving waste in 1978. Examples of waste placed in this burial ground include contaminated soil, decommissioned pumps, pressure vessels, and post-August 19, 1987 RCRA and state-only designated mixed waste, and retrievable TRU waste.

- The 218-W-5 Burial Ground (Figure 1-9) is approximately 37.2 hectares in size and began receiving waste in 1986. Examples of waste placed in this burial ground include rags, paper, rubber gloves, disposable supplies, broken tools, and post-August 19, 1987 RCRA and state-only designated mixed waste. This burial ground currently contains double-lined mixed waste trenches (trenches 31 and 34) (Figure 1-10). Adjacent to the double-lined mixed waste trenches are leachate collection tanks operated in accordance with the generator provisions of WAC 173-303-200. Examples of waste to be placed in the double-lined mixed waste trenches include mixed waste that has been treated to meet LDR requirements (including containerized bulk waste) and macroencapsulated long-length contaminated equipment.

- The 218-W-6 Burial Ground (Figure 1-11) is approximately 16 hectares in size, has not received any waste, and is reserved for future mixed waste disposal.

\subsubsection{How Waste is Accepted, Moved, Processed, and Managed}

The following sections and the flowchart (Figure 2-1) describe the different types of information and knowledge used for waste acceptance.

\subsubsection{Narrative Process Descriptions}

The onsite generating unit, offsite generator, and the treatment, storage, and/or disposal (TSD) unit transferring waste to the LLBG is hereafter referred to as the 'generator'. All mixed waste is disposed in lined mixed waste trenches or other approved alternatives. Waste accepted either can be containerized or bulk solids.

Mixed waste that meets LDR requirements, as specified in 40 CFR 268 and WAC 173-303-140, is disposed in lined trenches with leachate collection and removal systems. The Hanford Facility is required to test certain mixed waste depending on the type of treatment standard to ensure that the waste or treatment residuals are in compliance with applicable LDR requirements. Such testing is performed according to the frequency specified in this WAP. 


\begin{abstract}
Defueled reactor compartments are disposed in Trench 94 of the 218-E-12B Burial Ground under an exemption allowed by WAC 173-303-665(2)(b).
\end{abstract}

\title{
1.1.1.2 Waste Acceptance Process
}

The LLBG waste acceptance process consists of the following activities.

- Waste Stream Approval. The generator provides information concerning each waste stream on a waste profile sheet. The waste stream information is reviewed against the LLBG waste acceptance criteria. However, waste that previously was accepted at a Waste Management Project operated TSD unit does not require the development or redevelopment of a waste profile and is exempt from the waste stream approval function. If the waste stream information is sufficient and meets the applicable acceptance criteria, the waste stream is approved ${ }^{1}$. In addition, the initial verification frequency for the waste is determined in accordance with the requirements found in the performance evaluation program (PES) (Section 1.1.1.3). For a more complete description of the waste stream approval process, refer to Section 2.1.1.

- Waste Shipment Approval. The generator provides specific data for each waste container. The container data are reviewed against the waste profile sheet data and the LLBG acceptance criteria before being approved for shipment. In addition, the LLBG operating organization or its representative, hereafter referred to the 'LLBG operating organization', determines if any of the containers require verification based on the verification frequency as determined by PES. For a more complete description of the waste transfer/shipment approval process, refer to Section 2.1.2.

- Verification. Verification activities include container receipt inspection and also could include physical screening and/or chemical screening. All containers received at the LLBG are receipt inspected before acceptance, and a percentage of waste containers are selected for physical and/or chemical screening during the waste shipment approval process. These containers can be inspected visually, verified by nondestructive examination (NDE), or sampled for field or laboratory analysis to confirm that the waste matches the waste profile and container data information supplied by the generator. Any discrepancies between the verification results and the waste profile sheet must be resolved before final acceptance at LLBG in accordance with the conformance issue resolution process found in Section 1.1.1.3.3.

\subsection{Types of Acceptable Knowledge}

When collecting documentation on a waste stream or container, the LLBG operating organization must determine if the information provided by the generator is acceptable knowledge. Acceptable knowledge requirements are met using any one or combination of the following types of information:

- Mass balance from a controlled process that has a specified output for a specified input

- Material safety data sheet (MSDS) on unused chemical products

- Test data from a surrogate sample

- Analytical data on the waste or a waste from a similar process.

\footnotetext{
' Approved waste profiles are retained in the LLBG operating record and will be made available upon request.
} 
1 In addition, acceptable knowledge requirements can be met using a combination of analytical data or

2 screening results and one or more of the following:

3

4

5

6

- Interview information

- Logbooks

- Procurement records

- Qualified analytical data

- Radiation work package

- Procedures and/or methods

- Process flow charts

- Inventory sheets

- Vendor information

- Mass balance from an uncontrolled process (e.g., spill cleanup)

- Mass balance from a process with variable inputs and outputs (e.g., washing/cleaning methods).

If the information is sufficient to quantify the constituents of regulatory concern and determine waste characteristics as required by the regulations and LLBG acceptance criteria, the information is considered acceptable knowledge. The LLBG acceptance criteria are defined as the requirements found in this WAP and the associated Part A, Form 3 (DOE/RL-88-20).

\subsubsection{Description of Performance Evaluation System}

The PES determines the initial physical screening frequency of each generator waste stream. PES provides a periodic status of an individual generator's performance for waste received. Also, a PES provides a mechanism for determining corrective actions, resolving waste acceptance issues, and physical screening adjustments when a problem has been discovered.

\subsection{Initial Physical Screening Frequency Determination}

The initial physical screening frequency is determined based on the following process.

- LLBG operating organization reviews the generator profile information to determine the relative potential for misdesignation or inappropriate segregation based on all relevant information, including any previous experience with the generator. Based on this review, LLBG operating organization identifies any concerns associated with the following criteria:

- documented waste management program

- waste stream characterization information

- potential for inappropriate segregation.

- Based on the identification of concerns during the review, the LLBG operating organization establishes the initial physical screening frequency for the generator's waste stream based on the following criteria:

- Initial physical screening frequency of, at a minimum, 20 percent: No concerns identified

- Initial physical screening frequency of, at a minimum, 50 percent: Concern(s) identified in one criterion

- Initial physical screening frequency of 100 percent: Concerns identified in two or more criteria. 


\subsection{Monthly Performance Evaluation}

A monthly performance evaluation is used to trend a generator's performance and is used to raise the generator's overall group of streams physical screening frequency based on the type of issue. The evaluation should be objective and should consider the conformance issues documented during the preshipment review and verification functions. The LLBG operating organization will: (1) perform monthly evaluations based on deficiencies and conformance issues identified, (2) evaluate unsatisfactory performance for corrective actions, and (3) adjust physical screening rates accordingly.

\subsection{Conformance Issue Resolution}

Conformance issues identified during verification could result in a waste container that does not meet the LLBG waste acceptance criteria. If a possible conformance issue is identified, the following actions are taken to resolve the issue.

- LLBG operating organization compiles all information concerning the possible conformance issue(s).

- The generator is notified and requested to supply additional knowledge to assist in the resolution of the concern(s). If the generator supplies information that alleviates the concern(s) identified, no further action is required.

- Upon determination that a conformance issue has been identified, the LLBG operating organization personnel and the generator discuss the conformance issue and identify the appropriate course of action to resolve the container/shipment in question, i.e., pick another sample set, return the container/shipment, divert the container/shipment to another TSD unit and resolve the issue, or the generator resolves the issue at the TSD unit. If the conformance issue(s) results in the failure of a shipment, the physical screening frequency for all stream(s) that could exhibit a similar issue (or issues) from the generator are adjusted to 100 percent until the issue(s) adequately can be addressed.

- On resolution of the initial conformance issue, LLBG operating organization requests the generator to provide a corrective action plan (CAP) that clearly states the reason for the failure and describes the actions to be completed to prevent re-occurrence. The generator could request a reduction in verification of additional streams that the generator believes are unaffected. This request must be accompanied by a justification that identifies why this stream(s) would not exhibit the same conformance issue.

- LLBG operating organization reviews the CAP and stream justification for adequacy. If the stream justification is adequate, the LLBG operating organization could provide an alternative frequency as denoted in Section 1.1.1.3.2.

\subsection{Process for Reducing the Physical Screening Frequency}

Screening rate frequencies and changes to those frequencies could be applied to a specific waste stream, to a specific contractor, or to a specific offsite generator based on the circumstances surrounding the conformance issue. After the initial screening frequency for a given waste stream has been established or increased, the physical screening frequency can be reduced in accordance with the following process.

The physical screening frequency will be reduced in three steps. Reduction for all steps is based on the ability to demonstrate that five containers from the waste stream in question pass verification. In addition, reduction to the minimum frequency requires that the LLBG operating organization documents an acceptable evaluation of the CAP. At no time will the physical screening frequency be reduced below 5 percent for waste generated onsite or below 10 percent for offsite generators. 
- Step 1. Reduce frequency by a maximum of 66 percent after five containers from the waste stream in question pass verification.

- Step 2. Reduce frequency established in Step 1 by a maximum of 50 percent or to the minimum allowable, whichever results in a greater frequency after five containers from the waste stream in question pass verification.

- Step 3. Reduce frequency to the minimum allowable after five containers from the waste stream in question pass verification. The LLBG operating organization documents an acceptable evaluation of the CAP.

\subsubsection{Process Flow Diagram}

Refer to Figure 2-1 for the waste analysis plan flowchart and Section 1.1 for description.

\subsubsection{Operating Conditions}

Waste can be sent to the LLBG in a variety of container configurations, including drums, boxes, macroencapsulated items, and bulk waste that has sufficiently low concentrations of chemical and radiological constituents to be handled safely. For containerized waste, the container weight must be known and proper handing procedures are imposed to ensure safe operations. The waste container radiation dose must be known and procedures must ensure that personnel exposure is kept as low as is reasonably achievable (ALARA). The quantity of fissile material within the waste must be determined and must be low enough to prevent a criticality hazard. Free liquids are not allowed in waste, except that certain incidental liquids could be allowed as described in Section 1.2. Waste containers must be at least 90 percent full. Containers of waste that could develop pressure before placement in the disposal unit must be vented. Radionuclide and dangerous waste constituent inventories in waste containers must be kept low enough to ensure that personnel exposure limits are not exceeded.

The Part A, Form 3, permit application for LLBG identifies dangerous waste numbers, quantities, and design capacity (DOE/RL-88-21).

Dangerous and/or mixed waste with waste numbers not identified on the LLBG Part A, Form 3, will not be managed at LLBG. Additionally, waste for which LLBG are unable to obtain the information required by WAC 173-303-300 will not be managed in LLBG.

\subsection{IDENTIFICATION AND CLASSIFICATION OF WASTE}

Mixed waste is acceptable for disposal in the LLBG except for the following waste types.

- Waste is not accepted for disposal when the waste contains free-standing liquid unless all free-standing liquid:

- Has been removed by decanting or other methods

- Has been mixed with sorbent or stabilized (solidified) so that free-standing liquid is no longer observed

- Has been otherwise eliminated 


\section{HNF-5841}

- Container is very small, such as an ampoule

- Container is a labpack and is disposed in accordance with WAC 173-303-161 or 40 CFR 264.316

- Container is designed to hold free liquids for use other than storage, such as a battery or capacitor.

There could be cases in which small amounts of residual liquids are present in mixed waste containers because condensate has formed following packaging or free liquids remain in debris items (e.g., pumps, tubing) even after draining. When it is not practical to remove this residual liquid or impossible to sample to determine if liquids are present, the liquid must be eliminated to the maximum extent practical by draining and placing a quantity of sorbent sufficient to sorb all residual liquids in the bottom of the container or dispersed among the waste.

Free liquid is determined by SW-846, Method 9095 (Paint Filter Liquids Test)

[WAC 173-303-140(4)(b) and 40 CFR 264.314(d)] only for waste that has the potential for free liquid formation.

- Gaseous waste is not accepted for disposal if the waste is packaged at a pressure in excess of 1.5 atmospheres at $20^{\circ} \mathrm{C}$.

- Pyrophoric waste is not accepted for disposal. Waste containing less than 1 weight percent pyrophoric material partially or completely dispersed in each package is not considered pyrophoric for the purposes of this requirement.

- Solid acid waste is not accepted for disposal [WAC 173-303-140(4)(c)].

- Untreated extremely hazardous waste is not accepted for disposal. Extremely hazardous waste that has been treated could be disposed in accordance with the Revised Code of Washington (RCW) 70.105.050(2).

- Untreated organic/carbonaceous waste is not accepted for disposal [WAC 173-303-140(4)(d)], except as allowed by WAC 173-303-140(4)(d)(iii).

- Waste not meeting the applicable treatment standards is not accepted for disposal [40 CFR 268 and WAC 173-303-140(4)].

- Mixed waste that is incompatible with the liner system is not accepted in the LLBG. Table 1-1 provides a list of chemicals that have been shown to be incompatible with the liner material in concentrated form. In general, mixed waste that meets federal and state treatment standards is compatible with the LLBG liner system. Waste streams are evaluated during preshipment review to ensure that the waste streams do not contain constituents incompatible with the liner system in concentration sufficient to degrade the liner. 
HNF-5841

1

2

3

4

5

This page intentionally left blank.

000302.0901 

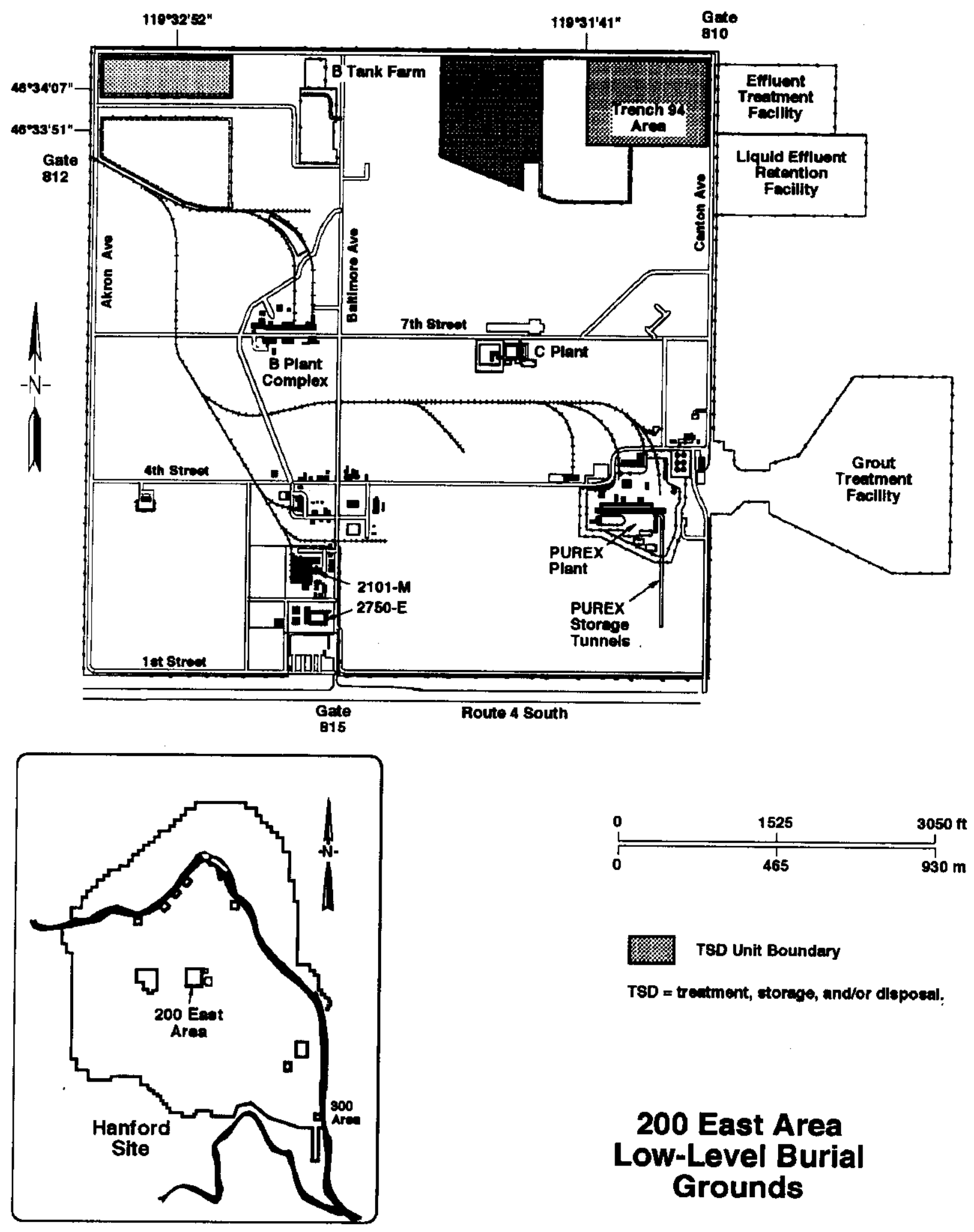

\section{East Area Low-Level Burial Grounds}

Figure 1-1. Locations of Low-Level Burial Grounds in the 200 East Area. 


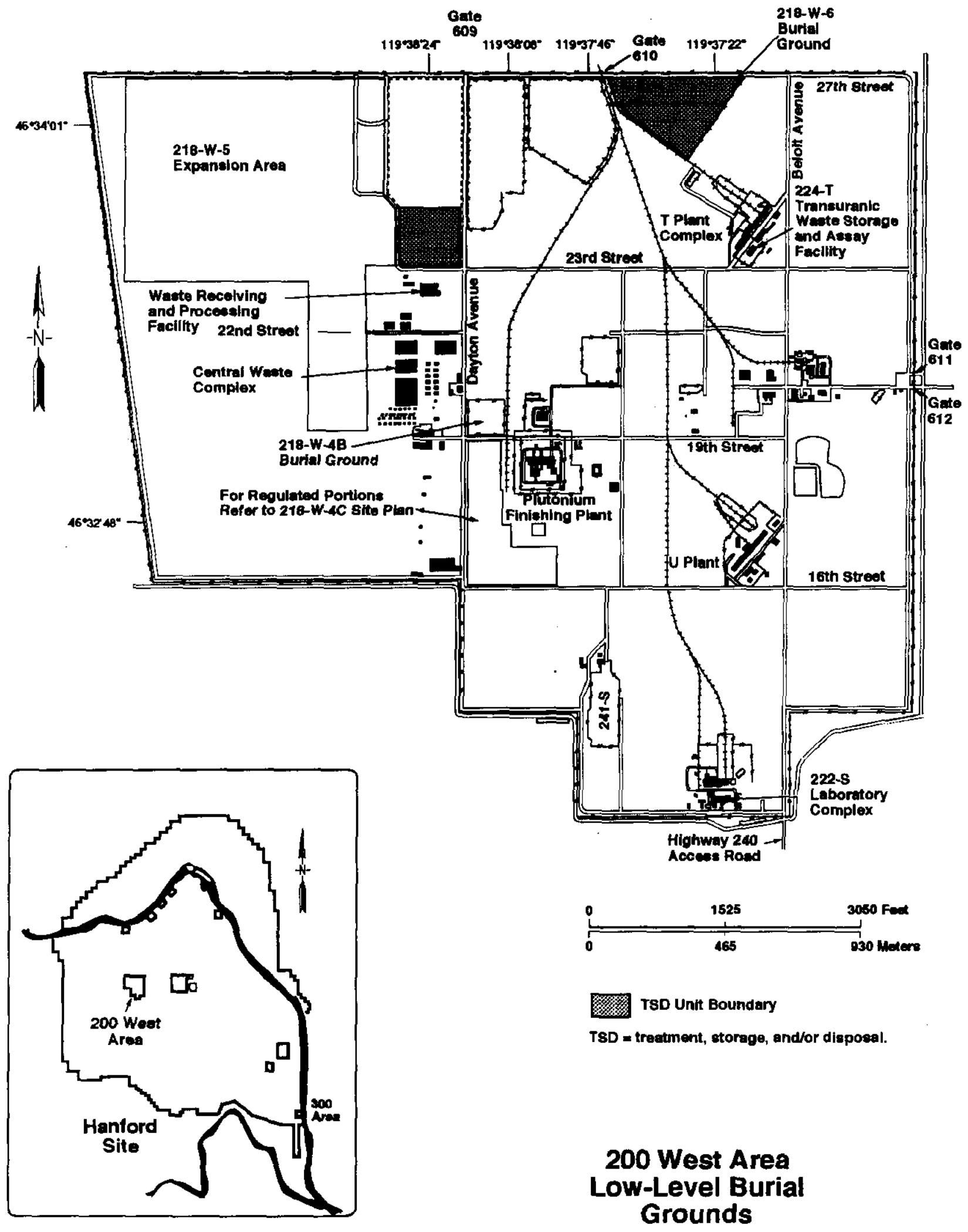

1000100642 A2 2-00

Figure 1-2. Locations of Low-Level Burial Grounds in the 200 West Area. 


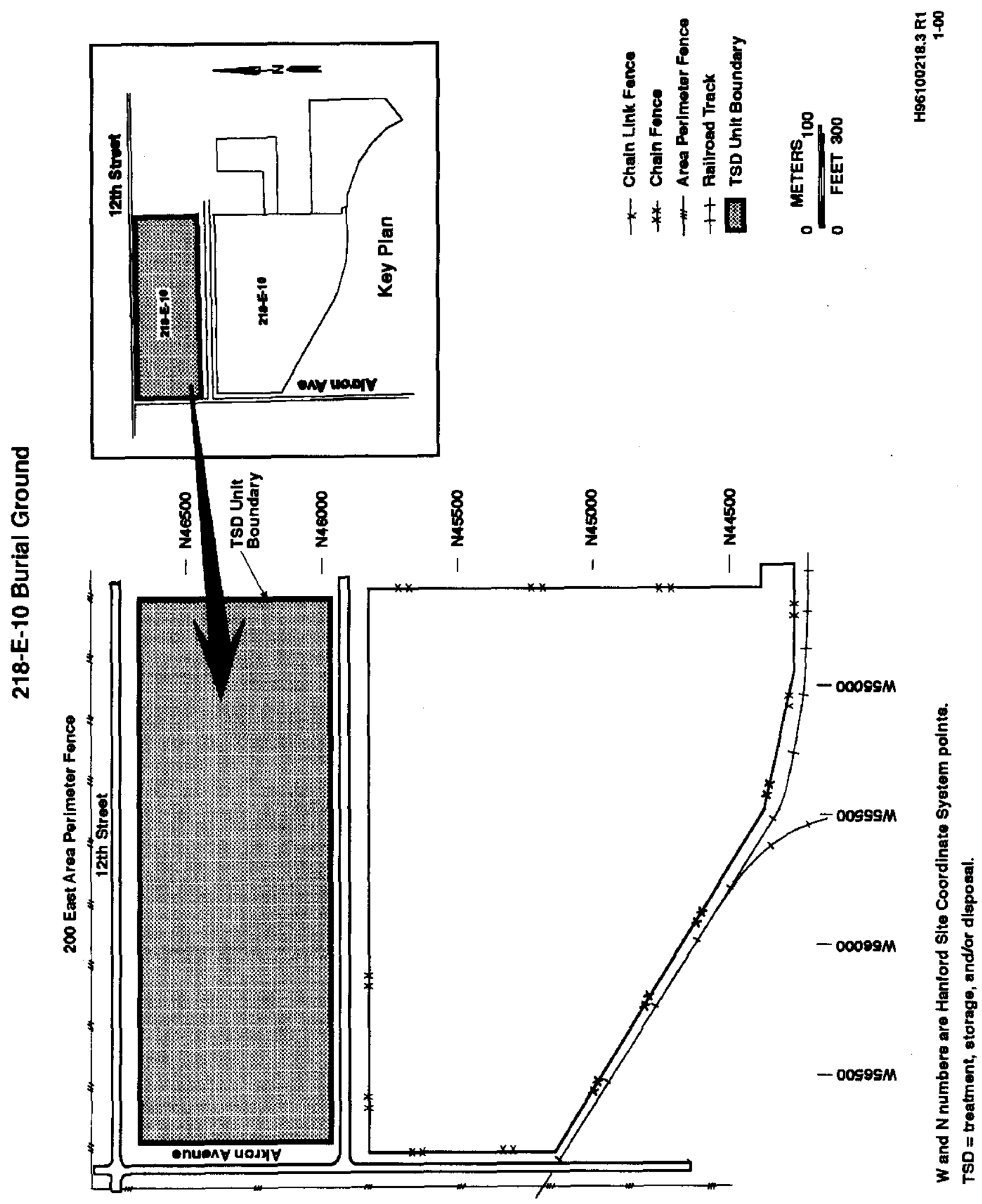

Figure 1-3. 218-E-10 Burial Ground. 




Figure 1-4. 218-E-12B Burial Ground. 
HNF-5841

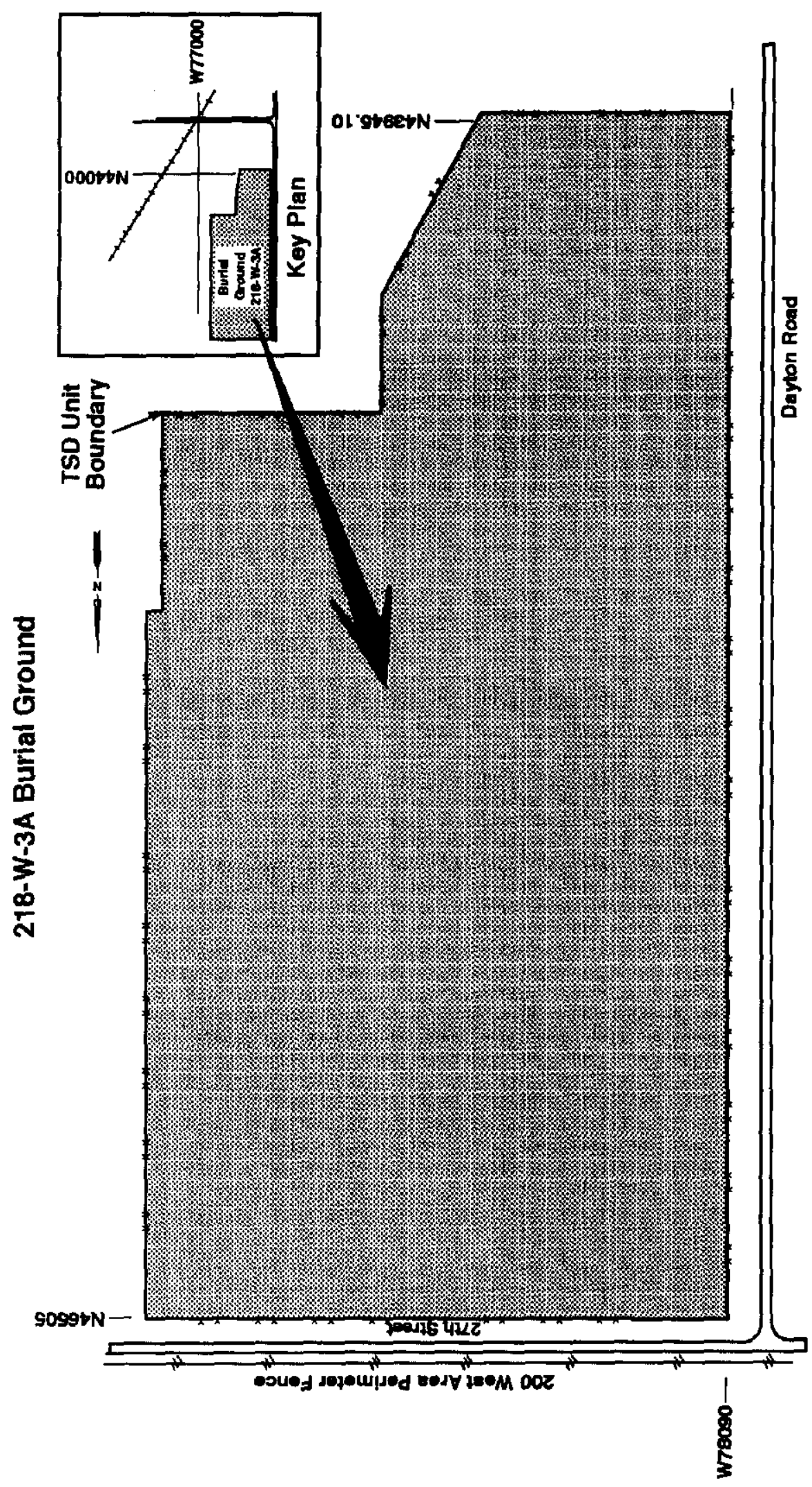

옹

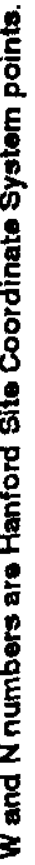

Figure 1-5. 218-W-3A Burial Ground. 


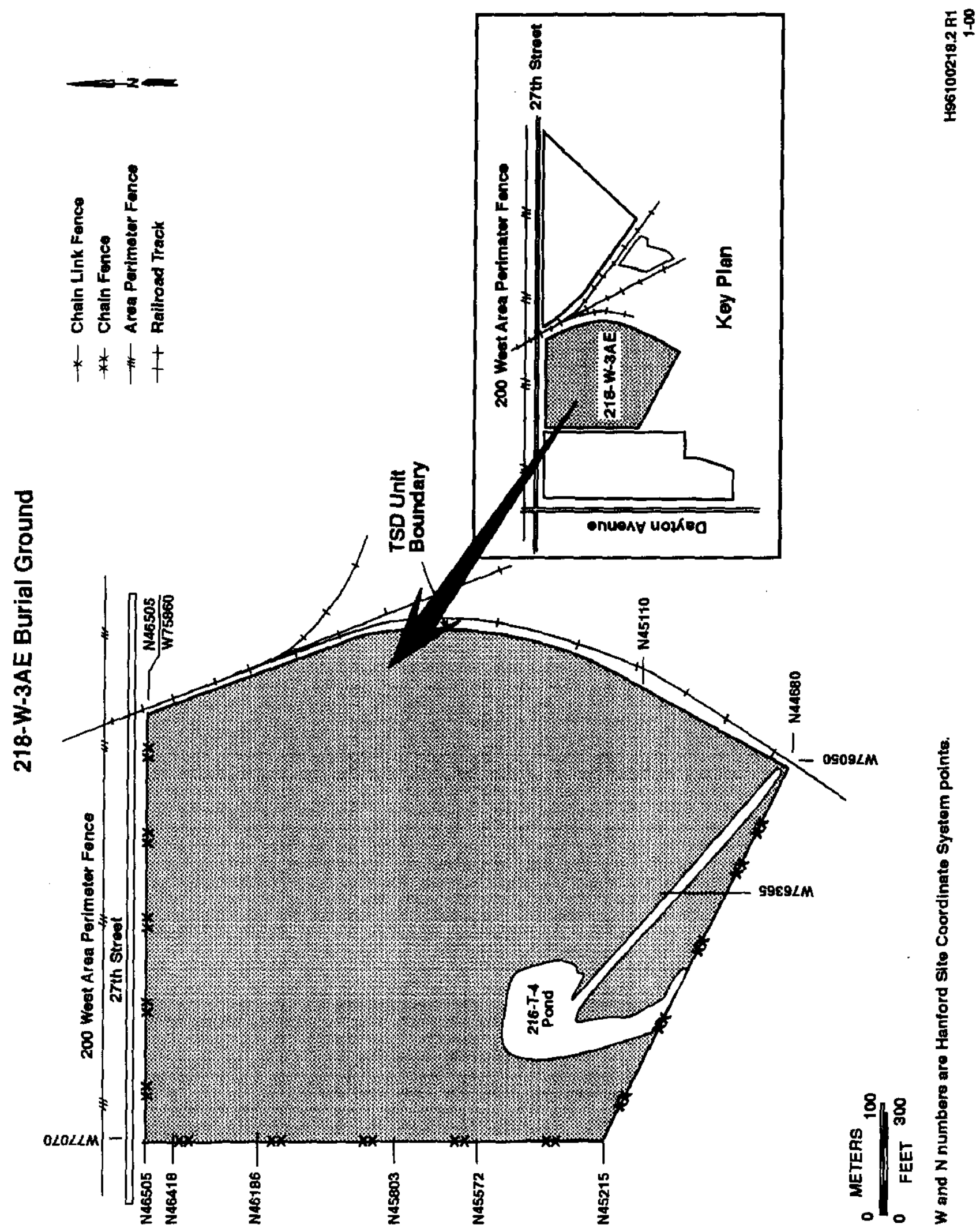

Figure 1-6. 218-W-3AE Burial Ground. 


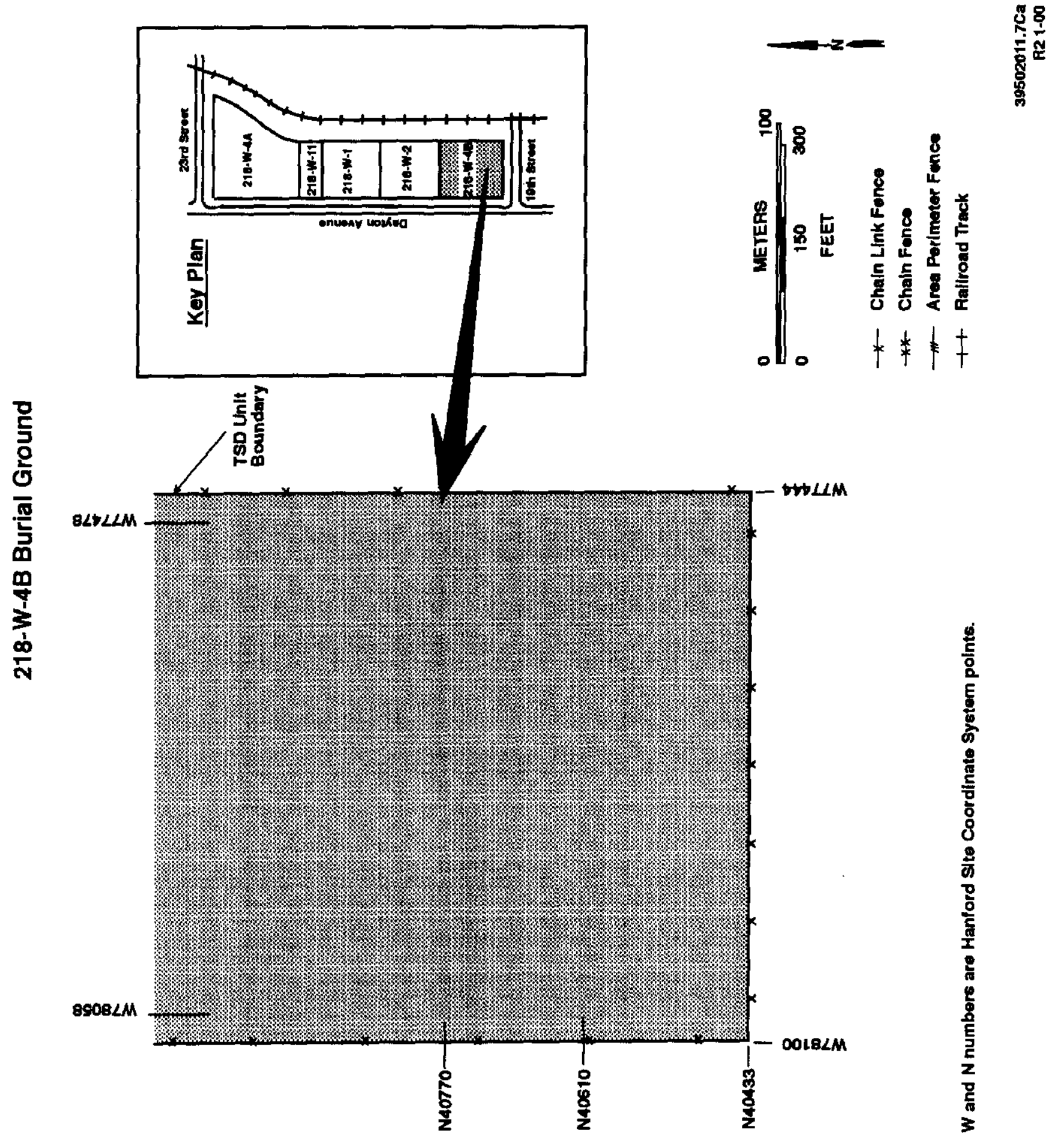

Figure 1-7. 218-W-4B Burial Ground. 
HNF-5841

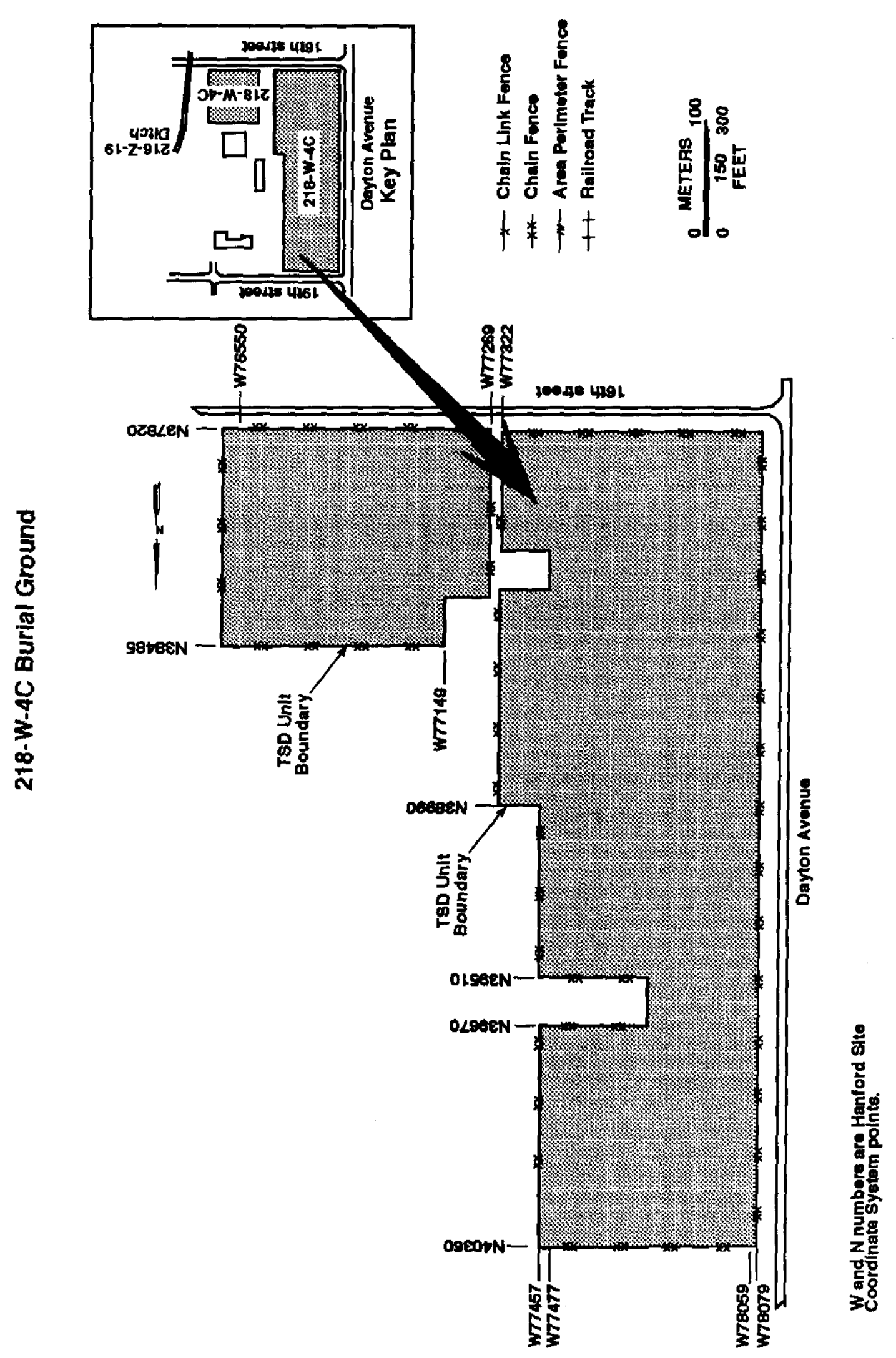

Figure 1-8. 218-W-4C Burial Ground. 
HNF-5841

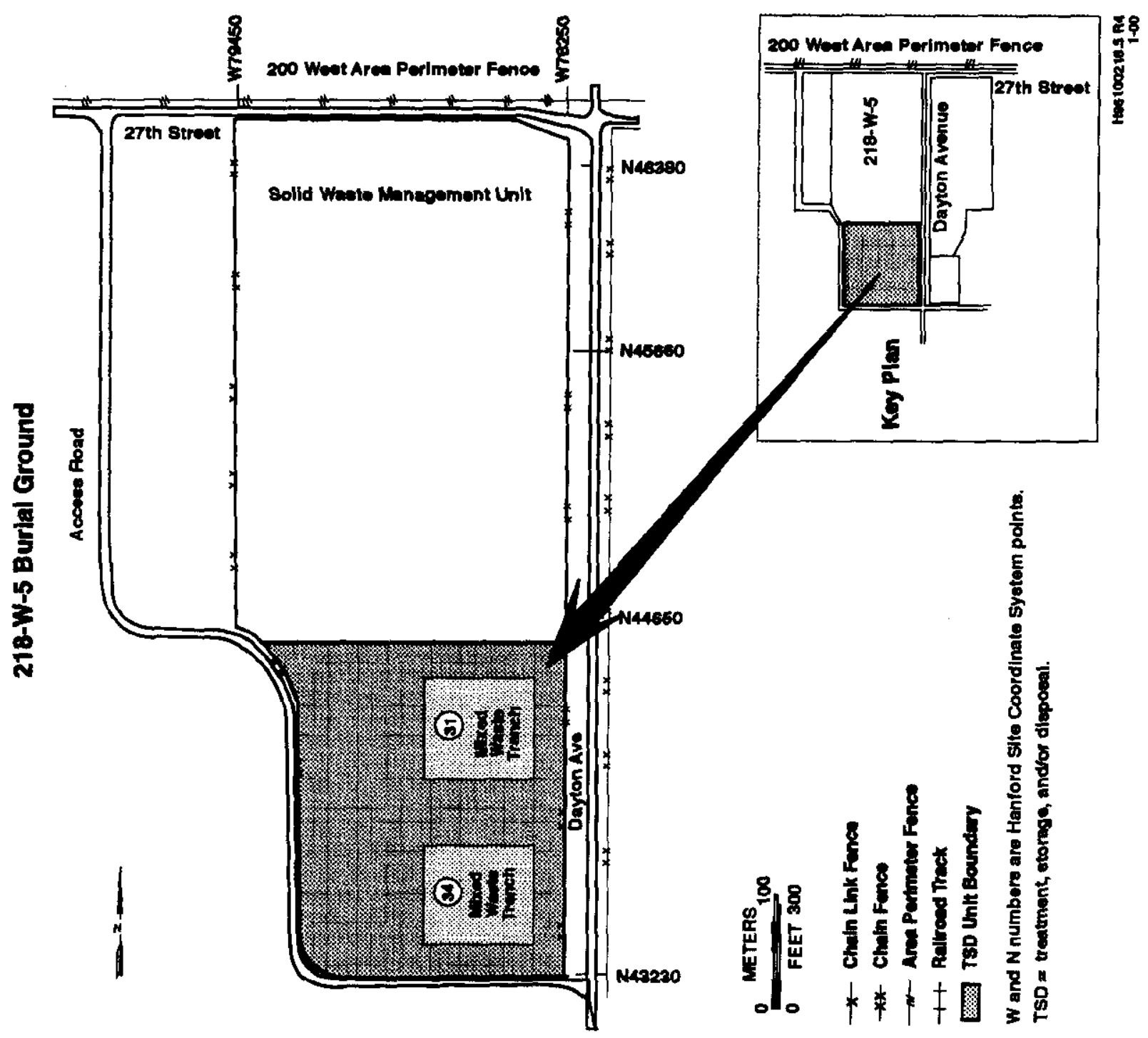

Figure 1-9. 218-W-5 Burial Ground. 


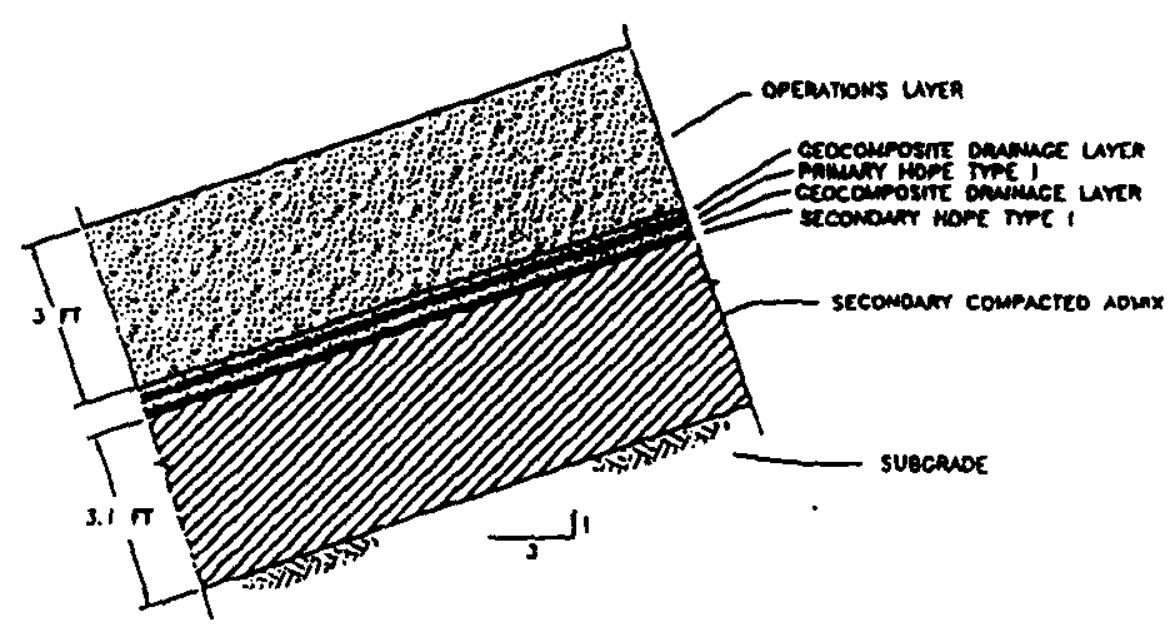

SIDESLOPE LINER DETAIL

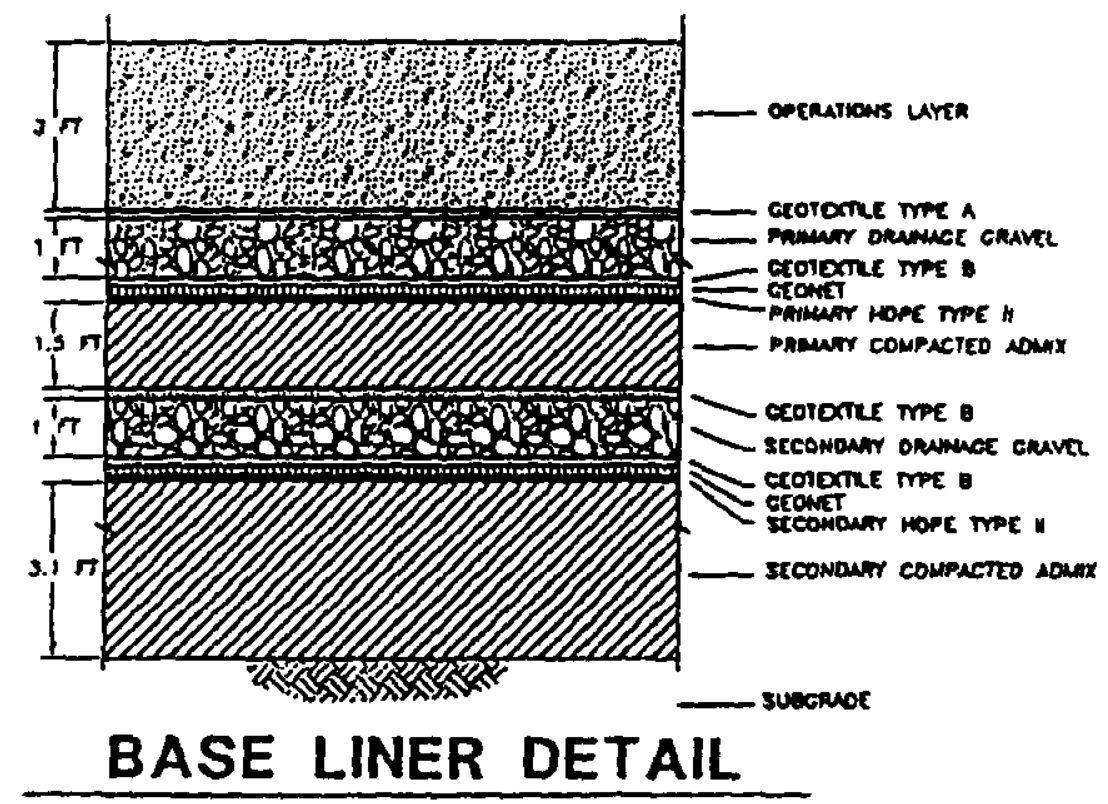

$3-3-949: 44$ ICaO9331214 42080

Figure 1-10. Typical Resource Conservation and Recovery Act-Compliant Liner System. 


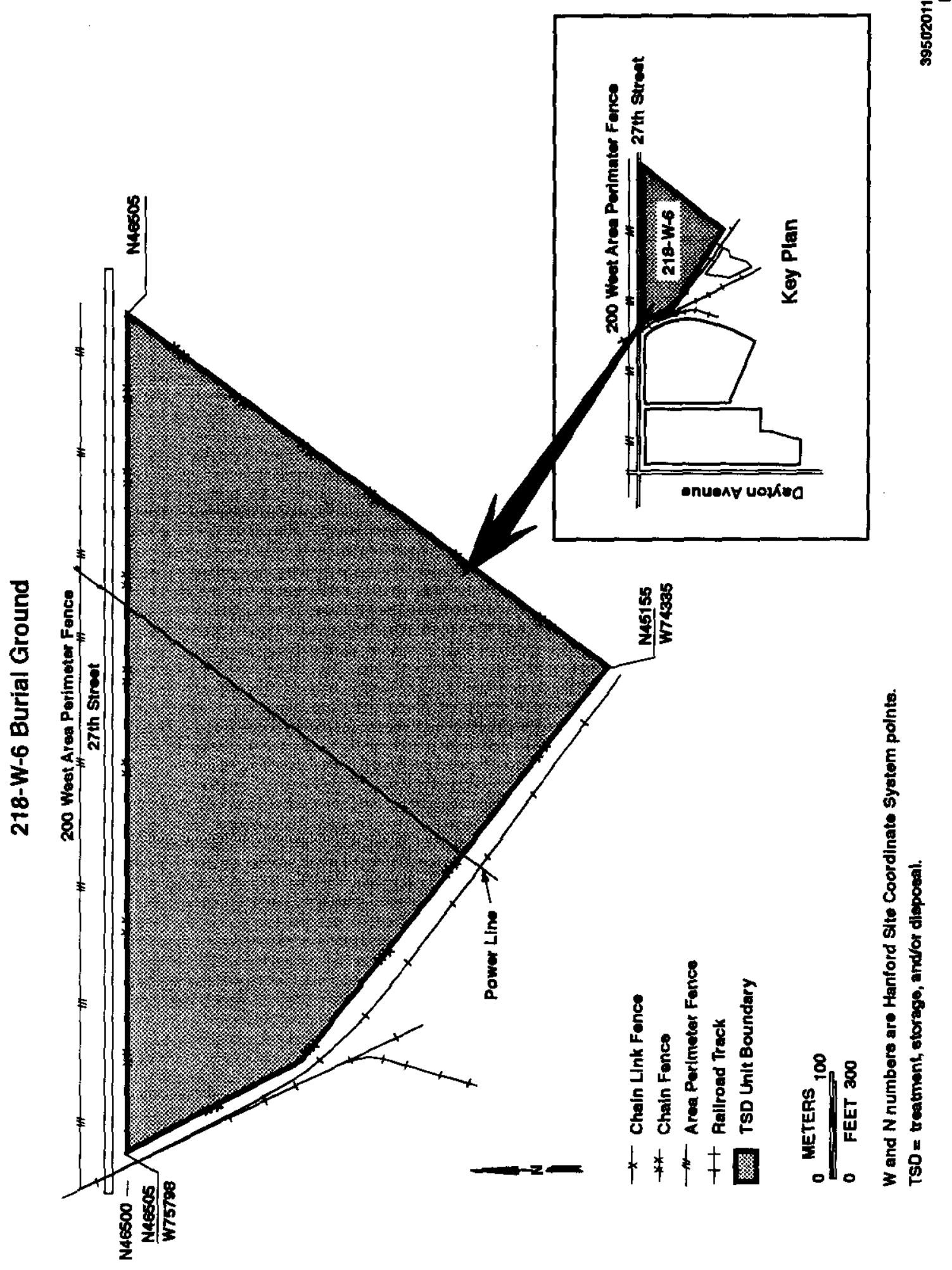

Figure 1-11. 218-W-6 Burial Ground. 


\section{HNF-5841}

This page intentionally left blank. 
Table 1-1. Chemicals Incompatible with the High-Density Polyethylene Liner (in concentrated form).

Amyl chloride

Aqua regia

Bromic acid

Bromobenzene

Bromoform

Calcium bisulfite

Calcium sulfide

Diethyl benzene

Diethyl ether

Elemental bromine
Elemental chlorine

Elemental fluorine

Ethyl chloride

Ethylene trichlorideNitrobenzene

Perchlorobenzene

Propylene dichloride

Sulfur trioxide

Sulfuric acid (fuming)

Thionyl chloride

Vinylidene chloride. 
HNF-5841

1

2

3

4

5

This page intentionally left blank. 
The confirmation process includes completing the appropriate pre-shipment reviews and verification steps and/or parameters.

\subsection{PRE-SHIPMENT REVEW}

Pre-shipment review takes place before waste can be scheduled for transfer or shipment to the LLBG. The review focuses on whether the waste stream is defined accurately, meets the LLBG waste acceptance criteria, and the LDR status determined correctly. Only waste determined to be acceptable for disposal is scheduled. This determination is based on the information provided by the generator. Except for transfers among Waste Management Project operated TSD units, the pre-shipment review consists of the waste stream approval and the waste shipment approval process. Previously accepted waste that is transferred from one Waste Management Project operated TSD unit to another does not require development or approval of a profile. The following sections discuss the pre-shipment review process. The information obtained from the generator during the pre-shipment review, at a minimum, includes all information necessary to safely store and/or dispose of the waste. The pre-shipment review ensures the waste has been characterized and the data provided qualify as 'acceptable knowledge' (Section 2.1.3).

\subsubsection{Waste Stream Approval Process}

The waste stream approval process consists of reviewing stream information supplied on a waste stream profile and attached analysis. At a minimum, the profile requests the following information:

- Generator information (e.g., name, address, point-of-contact, telephone number)

- Waste stream name

- Waste generating process description

- Radiological knowledge (e.g., classification, reportable radionuclides, characterization method)

- Chemical characterization information (e.g., characterization method(s), chemicals present, concentration ranges)

- Designation information

- LDR information including identification of underlying hazardous constituents if applicable

- Waste type information (e.g., physical state, sorbents used, stabilizing agents used)

- Packaging information (e.g., container type, maximum weight, size)

- Attachments could consist of container drawings, process flow information, analytical data, etc.

In some cases, such as variable waste streams, the profile information can be general in nature. In these cases, more detailed information will be gathered during the waste shipment approval process. This 
information is reviewed against the LLBG waste acceptance criteria to ensure the waste is acceptable for receipt. If discrepancies are found during this review, additional information is requested that could include analytical data or a sample to be analyzed. If the waste cannot be received, the LLBG operating organization will pursue acceptance of the waste at an alternative TSD unit or request the generator to pursue acceptance at an offsite facility.

On determination that the waste is acceptable, the LLBG operating organization assigns the profile to a waste management path and establishes a waste verification frequency based on the requirements found in Sections 1.1.1.3 and 2.2.2.2.

\subsubsection{Waste Shipment Approval Process}

For each waste transfer or shipment that is a candidate for disposal in the LLBG, the generator provides the following information:

- Container identification number

- Profile number (except for waste transfers of previously accepted waste)

- Waste description

- Generator information (e.g., name, address, point-of-contact, telephone number)

- Container information (e.g., type, size, weight)

- Waste numbers

- LDR certification (when required)

- Extremely hazardous waste or dangerous waste

- Dose rate information

- Reportable radionuclides and quantities

- Waste composition

- Packaging materials and quantities.

The pertinent information is entered into Solid Waste Information Tracking System (SWITS). Figure 2-1 is the waste acceptance process.

Where potential nonconformances exist in the information provided (i.e., waste characteristics do not match the waste profile information/LLBG waste acceptance criteria, or additional constituents are expected to be present that do not appear on the documentation), the generator is contacted by the LLBG operating organization. Refer to Section 6.0 for discussion on repeat and review frequency.

For each container, a technical review, physical screening determination, and chemical screening determination are performed as follows.

- Technical review. Individual container data on waste not previously accepted are compared to the waste profile data to ensure the waste to be transferred/shipped to LLBG is as described by the waste profile. Every transfer or shipment is reviewed to ensure the waste meets the LLBG waste acceptance criteria.

Based on waste identification information provided, the waste designation is reviewed to ensure consistency with waste designations per WAC 173-303-070, to ensure that the waste is not prohibited from disposal in accordance with WAC 173-303-140, and for technical accuracy to ensure the waste meets the waste acceptance criteria. 
- Chemical screening determination. Individual containers within a transfer or shipment are selected based on a review of the contents listed in the associated documentation. Containers are selected at random unless variability within the stream is noted. In this case, containers representing different variations are selected (e.g., used oil, spent solvent).

On determining whether the transfer or shipment will be verified, the transfer or shipment is scheduled.

\subsubsection{Acceptable Knowledge Requirements}

The LLBG operating organization ensures that all information used to make waste management decisions are based on adequate characterization data, as described in the following sections. The LLBG operating organization evaluates the data to ensure that the data are adequate acceptable knowledge for management of the waste.

\subsubsection{General Acceptable Knowledge Requirements}

Adequate acceptable knowledge includes (1) general waste knowledge requirements, (2) LDR waste knowledge requirements, and/or (3) waste knowledge exceptions.

(1) General Waste Knowledge Requirements. At a minimum, the generator supplies enough information for the waste to be managed at the LLBG. The minimum level of acceptable knowledge consists of designation data where the constituents causing a waste number to be assigned are quantified, and the data address any LLBG operational parameters necessary for proper management of the waste.

Where the available information does not qualify as acceptable knowledge or is not sufficient to characterize a waste for management, the sampling and testing methods outlined in WAC 173-303-110 must be used to determine whether a waste designates as toxic characteristic, corrosive, and/or contains free liquids.

If a generator's process knowledge indicates that constituents, which if present in the waste might cause the waste to be regulated, are input to a process but not expected to be in the waste, sampling and analysis must be performed to ensure the constituents are not present above regulatory limits in the waste. This requirement can be met through chemical screening as long as the constituents of concern 


\section{HNF-5841}

can be measured by the screening method. Sampling and analysis are required only for initial characterization of the waste stream.

(2) LDR Waste Knowledge Requirements. Waste can be placed in the LLBG only if the waste meets all applicable treatment standards. The LLBG operating record contains all information required to document that the appropriate treatment standards have been met. For waste that does not meet all applicable treatment standards, the waste is transferred to another TSD unit for proper disposition.

For the purposes of this WAP, a representative sample is required to demonstrate compliance with a concentration-based treatment standard (refer to Section 4.0). Corroborative testing for the sample could be accomplished in the following manner.

- Generators could use onsite laboratories or other laboratories to certify that the waste meets LDR requirements.

- The LLBG operating organization uses these analytical data ensure that the applicable requirements found in 40 CFR 268.7 and WAC 173-303-140(4) are met.

(3) Waste Knowledge Exceptions. During TRU waste retrieval from existing LLBG trenches, the waste can be transferred to onsite treatment and/or storage units provided the waste meets the waste acceptance criteria for the receiving unit. In addition, hazardous debris, as defined in WAC 173-303-040, that is managed in accordance with 40 CFR 268.45 is not required to be sampled to meet federal and state-only LDR regulations.

\subsubsection{Methodology to Ensure Compliance with Land Disposal Restrictions Requirements}

All generators are subject to LDR requirements and are required to submit all notifications and certifications described in WAC 173-303-380(1)(l) or (m), as applicable. The following are general requirements for offsite notifications or onsite information and supporting documentation.

- The waste is subject to LDR and the generator or treatment facility has treated the waste. The generator or treatment facility supplies the appropriate LDR certification information (40 CFR 268).

- The waste is subject to LDR and the generator has determined that the waste meets the LDR as generated. The generator develops the certification based on process knowledge, and/or analytical data, and supplies the appropriate LDR certification information necessary to demonstrate compliance with the LDR treatment standards of 40 CFR 268 and WAC 173-303-140. State-only LDRs do not require this type of certification.

- The waste is subject to an exemption from a prohibition on landfill disposal. The generator submits a notice stating the waste is not prohibited from land disposal as required by 40 CFR 268.7(a)(3) and WAC 173-303-140(6).

When demonstrating that a concentration-based treatment standard has been met, a representative sample of the waste must be submitted by the generator or treatment facility for analysis. 


\subsection{VERIFICATION}

Verification is an evaluation performed by the LLBG operating organization to substantiate that the waste received at LLBG is the same as represented by the analysis supplied by the generator for the pre-shipment review. Verification is performed on waste received by LLBG. Verification includes container receipt inspection, physical screening, and chemical screening. Waste is not accepted by the LLBG operating organization until required elements of verification have been completed, including evaluation of any data obtained from verification activities.

All discrepancies identified during the verification process are resolved in accordance with Section 1.1.1.3.3.

\subsubsection{Receipt Inspection}

The container receipt inspection is a mandatory element of the confirmation process. Therefore, 100 percent of the transfers/shipments are inspected for damage and to ensure the waste containers are those indicated on the documentation. This activity is a mechanism for identifying any document discrepancies and damaged containers before acceptance. The container receipt inspection is performed by the LLBG operating organization at the LLBG or at another location. The LLBG operating organization ensures that the transfer/shipment: (1) is received in good condition, (2) is the waste indicated on the manifest or shipping papers, (3) has not been opened improperly after physical and/or chemical screening was performed, and (4) is complete.

For bulk shipments and remote-handled waste, the transfer/shipment is inspected to ensure the waste is that denoted in the documentation.

\subsubsection{Physical Screening Process}

Physical screening is considered an additional verification element. This section describes the requirement pertaining to methods, frequency, and exceptions concerning the use of physical screening as a verification activity. Physical screening could be performed before the waste is transferred/shipped to LLBG. When screening is performed at a location not within the Waste Management Project [e.g., Waste Receiving and Processing Facility (WRAP), CWC, T Plant Complex], unique tamper resistant seals are applied to each container examined. Selection, interpretation, and performance of the appropriate physical screening method(s) are conducted by qualified personnel.

Waste received before the establishment of a verification program must be verified when initially transferred to the LLBG. However, waste stored within the Waste Management Project that has been processed through a physical screening program does not require additional physical screening (i.e., current waste specification program, backlog confirmation program, 183-H Solar Evaporation Basins sampling program).

\subsubsection{Physical Screening Methods}

Each of the following physical screening methods, listed in order of preference, complies with the requirement to verify a waste. If a method other than 1 or 2 is used, the reasoning behind the method chosen must be documented in the operating record (refer to Section 3.1 for the criteria for choosing a physical screening method).

1. Visual inspection (opening the container)

2. Nondestructive examination (NDE) [real-time radiography (RTR)] 


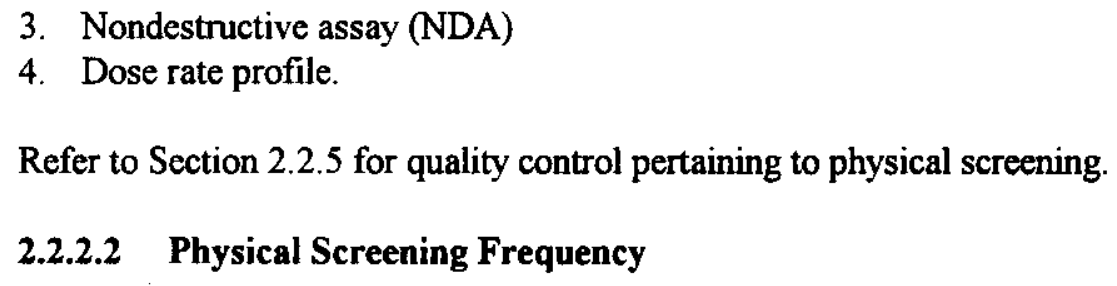

\subsubsection{Physical Screening Frequency}

The minimum physical screening frequency is 5 percent for onsite generating units, applied per waste stream per subcontractor per year ${ }^{2}$. For offsite generators, the minimum physical screening frequency is 10 percent per waste stream per generator per year. The LLBG operating organization adjusts the physical screening frequency for generators based on objective performance criteria (refer to Section 1.1.2).

In the event that one of the containers in the original sample set fails, a second sample set of equal size, or a minimum of three additional containers, is selected. First and second sample sets are selected using the rationale described in pre-shipment review section (Section 2.1). A second failure in either the first or second sample set constitutes failure of the transfer/shipment. If the second sample set passes the inspection, the single failed container is considered an anomaly and the remainder of the transfer/shipment passes verification. All failed containers and transfers/shipments are dispositioned by the PES as described in Section 1.1.1.3.

When physical screening is performed at a location not within the Waste Management Project, tamperresistant seals are applied to each outer container examined.

\subsubsection{Physical Screening Exceptions}

The following are exceptions to the physical screening process outlined previously have been developed.

- Shielded, classified, TRU waste retrieved from the LLBG, and remote-handled mixed waste are not required to be physically screened; however, the LLBG operating organization must perform a more rigorous documentation review and obtain the raw data used to characterize the waste $(<1$ percent of current waste receipts). For classified waste, it is necessary to have an appropriate U.S. Department of Energy (DOE) security clearance and a need to know the information as defined by the classifying organization or agency.

- Waste that physically cannot be screened at the LLBG or at an associated screening facility must be physically screened at the generator location (e.g., large components, containers that cannot be opened, are greater than 20 millirem per hour at 30 centimeters, contain greater than 10 nanocuries per gram of TRU radionuclides, or will not fit into the NDE unit). If no location can be found to perform the physical screening, no screening is required.

- Waste that is packaged by a Waste Management Project TSD operating organization (e.g., CWC, T Plant, WRAP) is considered to have met the physical screening requirements denoted in this WAP. On closure of the container, tamper-resistant seals must be applied to ensure the integrity of the contents.

\footnotetext{
${ }^{2}$ The term waste stream as referred to in the context of physical screening frequency refers to general waste groupings for treatment/disposal and should not be equated to the waste streams referred to in the waste profile discussion.
} 


\subsubsection{Chemical Screening Process}

2 Chemical screening is considered an additional verification element. This section describes methods, frequency, and exceptions for chemical screening. Chemical screening could be performed by the LLBG operating organization before the waste is transferred/shipped to LLBG. After chemical screening is performed, tamper-resistant seals are applied on each outer container screened. The requirements described for tamper-resistant seals used for physical screening apply to chemical screening as well.

Selection, interpretation, and performance of the appropriate chemical screening method(s) are conducted by qualified personnel. Unless otherwise noted, tests are qualitative not quantitative. The objective of chemical screening is to obtain reasonable assurance that the waste received is consistent with the description of the waste on the waste profile, and to provide information that will be used to safely manage the waste. The following tests are selected depending on the waste matrix and the applicability of the method. A minimum of three listed screening tests, including $\mathrm{pH}$ screening, are conducted on each sample. If less than five of the following methods are selected, the rationale is recorded by the qualified analyst.

The following tests are conducted on all samples collected for chemical screening:

- $\mathrm{pH}$

- Oxidizer

- Water reactivity

- Paint filter liquids test

Additionally, the following tests could be performed as needed:

- HOC (chlor-n-oil/water/soil)

- Ignitability/headspace screening for volatile compounds.

- Sulfide

- Cyanide

- Peroxide

Refer to Section 2.2.5.2 for quality control pertaining to chemical screening.

\subsubsection{Chemical Screening Frequency}

At a minimum, 10 percent of the waste containers verified by physical screening (Section 2.2 .2 .2 ) must be screened chemically. Although grab samples are acceptable, the LLBG operating organization obtains a representative sample.

Small containers of mixed waste (labpacks), not otherwise identified in the exceptions, packaged in accordance with 40 CFR 265.316 and WAC 173-303-161 are screened chemically in accordance with the waste stream's chemical screening frequency as determined by PES (Section 1.1.1.3). Inner containers are segregated by physical appearance. At least one container from each group (or three containers if all similar) are screened chemically.

\subsubsection{Chemical Screening Exceptions}

47 The following are cases in which chemical screening is not required: 
- Small containers of waste in overpacked containers (labpacks) packaged in accordance with WAC 173303-161 and not prohibited under the LDR provisions of WAC 173-303-140.

- Waste exempted from the physical screening requirements (Section 2.2.2.3) is exempted from chemical screening

- Commercial chemical products in the original product container(s) (e.g., off-specification, outdated, or unused products)

- Chemical containing equipment (mixed waste) removed from service (i.e., ballasts, batteries)

- Hazardous debris as defined in WAC 173-303-040

- Waste containing asbestos

- Waste, environmental media, and/or debris from the cleanup of spills or release of single substance or commercial product or otherwise known material (e.g., material for which a MSDS can be provided)

- Confirmed noninfectious mixed waste (i.e., xylene, acetone, ethyl alcohol, isopropyl alcohol) generated from laboratory tissue preparation, slide staining, or fixing processes.

Other special cases could be exempted from chemical screening on a case-by-case basis.

\subsubsection{Sampling for Confirmation Screening}

Sampling is performed in accordance with WAC 173-303-110(2). A representative sample is obtained for chemical screening. The chemical screening methods described in Section 3.0 do not require any sample preservation methods because the screening tests are performed at the time and location of sampling, or as soon as possible thereafter. During the interim period, the samples are stored in a manner that maintains chain of custody and protects the sample composition.

The equipment requirements in Section 4.0, Table 4-1, apply to sampling for chemical screening. In addition, the following sampling equipment could be used in sampling for chemical screening: (1) for liquids and slurries - dip, tank, bomb, and bailer samplers, as well as tube-type samplers (e.g., thin-walled Shelby tubes, split spoons, probes, pipettes); and for sludges and solids - tube-type samplers (as previously mentioned) and augers; and for small containers, a spoon could be used in place of a scoop.

\subsubsection{Quality Assurance and Quality Control for Confirmation Process}

The following quality assurance (QA) and quality control (QC) elements are used by the LLBG operating organization to ensure confirmation activities provide sufficient data to provide an indication that waste received is as described in the transfer/shipment documentation.

\subsubsection{Physical Screening Quality Control}

This section describes the QC used by the LLBG operating organization or its representative to ensure that quality data are obtained when performing physical screening methods identified in Section 2.2.2, except 
1 visual inspection. Visual inspection does not consist of the use of instrumentation or chemical tests.

2 Therefore, QC for visual inspection depends on appropriate training for the individual(s) performing the test.

3 For the remaining physical screening tools (NDE, NDA, and dose rate profile), QC for these methods is

4 incorporated in accordance with manufacturer's instructions or site-specific protocols. If any results are

5 questionable, those affected containers must be re-evaluated and handled appropriately.

6

\subsubsection{Chemical Screening Quality Control}

8 This section describes the QC used by the LLBG operating organization or its representative to ensure that

9 appropriate data are obtained when performing chemical screening methods identified in Section 2.2.3.

10

11

The following applies for all chemical screening parameters.

- Each lot will be evaluated to determine that the lot is useable. Unstable reagents will be accounted for when determining the usability of the lot.

- For each lot, the source, concentration, date of receipt, lot number, and manufacturer/preparer (as applicable) will be maintained in a logbook.

- For individual chemical screening parameters, QC checks will be performed in accordance with manufacturer's instructions or site-specific protocols. 


\section{HNF-5841}

1

2

3

4

5

This page intentionally left blank. 

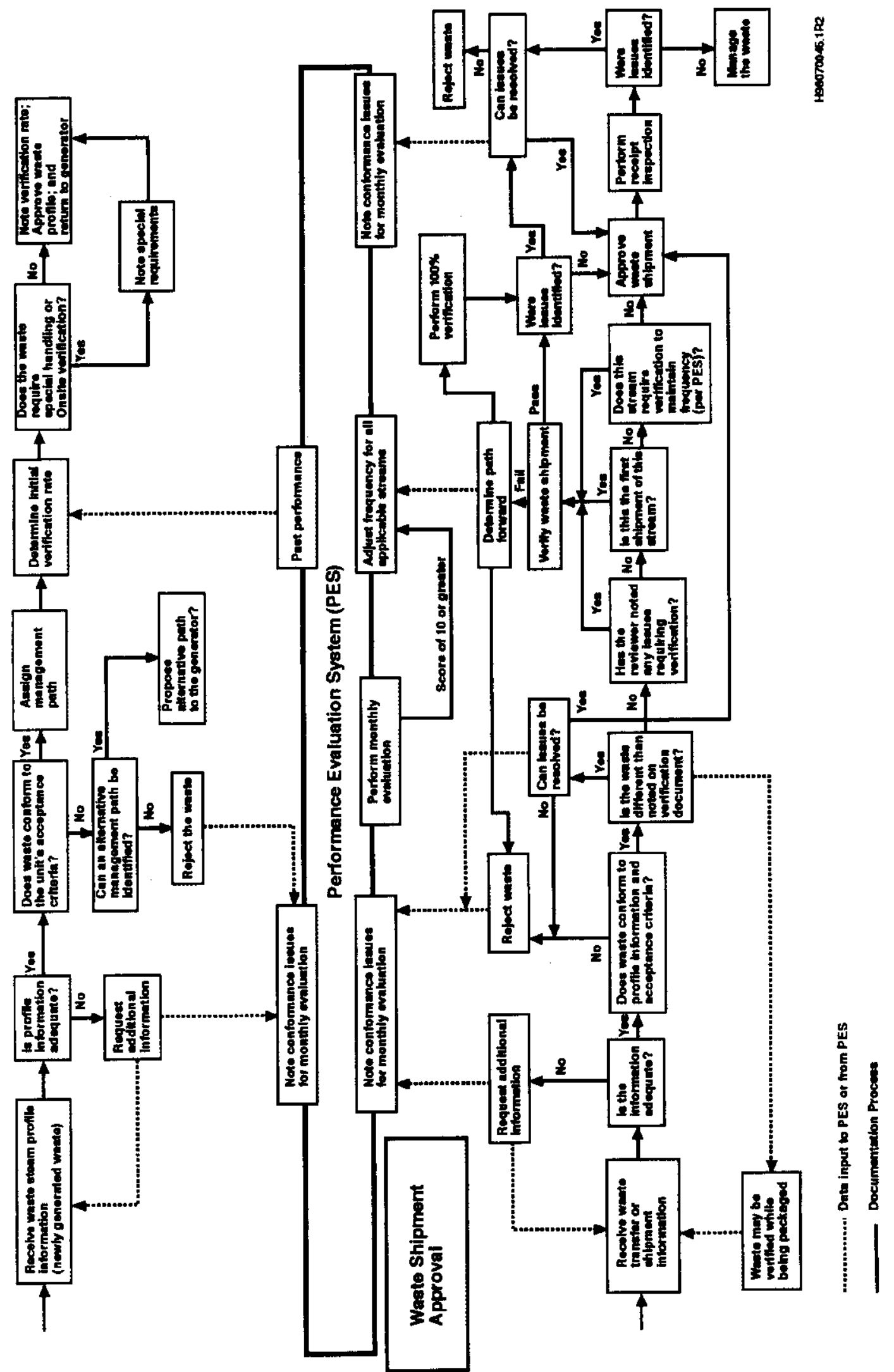

Figure 2-1. Waste Acceptance Process. 


\section{HNF-5841}

1

2

3

4

This page intentionally left blank. 
HNF-5841

\title{
3.0 SELECTING WASTE ANALYSIS PARAMETERS
}

\begin{abstract}
Physical and chemical screening parameters for verification must be chosen from those in Sections 3.1 and 3.2. Other sampling and analysis parameters are addressed in Section 3.3.
\end{abstract}

\subsection{PHYSICAL SCREENING PARAMETERS}

The following methods are approved for use in performing physical screening. These methods are listed in order of preference. If a method other than 1 or 2 is used, the reasoning behind the method selection will be documented.

(1) Visual inspection (preferred method for physical screening):

Rationale. This method meets the requirement to ensure consistency between waste containers and the accompanying transfer/shipment documentation.

Method: The container is opened and the contents are removed as needed for visual examination. Homogenous loose solids are probed to determine the presence of material not documented, or for improperly sorbed liquids. Visual observations are compared with the applicable profile information and the container specific information in the transfer/shipment documentation.

Failure criteria: A container fails the inspection for any of the following reasons: (a) undocumented or improperly packaged waste; (b) discovery of prohibited articles or materials listed in Section 1.2;

(c) discovery of material not consistent with the applicable waste stream profile; and (d) variability greater than 25 percent by volume in listed constituents (e.g., paper, plastic, cloth, metal).

(2) NDE:

Rationale. This method meets the requirement to ensure consistency between waste containers and the accompanying transfer/shipment documentation. This method also is subject to the QC checks listed in Section 2.2.5.1. Containers that are not easily amenable to visual inspection because of physical or radiological content, or facility availability, can be examined safely and economically.

Method: The container is scanned with a NDE system. Data are observed on a video monitor and captured on video tape. Personnel experienced with the interpretation of NDE imagery record their observations. These observations are compared to the contents listed on the transfer/shipment documentation.

Failure criteria: A container fails the inspection for any of the following reasons: (a) undocumented, improperly packaged, or inadequately sorbed liquids; (b) discovery of prohibited articles listed in Section 1.2 ; (c) image data not consistent with the applicable waste stream profile; and (d) variability greater than 25 percent by volume in listed constituents (e.g., paper, plastic, cloth, metal).

(3) NDA:

Rationale. This method is available for obtaining data that can be compared with accompanying transfer/shipment documentation for consistency on containers that cannot be opened for visual inspection, and cannot be examined by NDE (e.g., high container dose rate, shielding). The reason for selection of this method is documented. 
Method. Radioactive waste is assayed in one or both of two different assay systems. The assay systems include gamma energy analysis (GEA) and imaging passive/active neutron (IPAN). Gamma emitting radionuclides are detected in the GEA assay system. This instrument determines the type and quantity of radionuclides based on their gamma energy spectrum. IPAN uses passive and active neutron detection to determine the presence of fissionable radionuclides. Passive detection results are equated with $\mathrm{Pu}-240$ and active detection results are equated with $\mathrm{Pu}-239$. The curie amount of low energy gamma emitting radionuclides, other fissile and non-fissile alpha emitting radionuclides, and beta emitting radionuclides are calculated from the GEA and IPAN data and the generator supplied radionuclide information. Radionuclide ratios are calculated by dividing the activity of each radionuclide reported by the activity of the most prominent radionuclide.

Failure criteria. A container fails the assay if the difference between the reported radionuclide ratios and the measured ratios and the reported and measured curie amounts exceed 50 percent. The failure criteria are adjusted based on the density of the waste and the amount of fissionable material present.

(4) Dose rate profile:

Rationale. This method is used to obtain data that can be compared for consistency with the transfer/shipment documentation for a container. This method is used only when the previous three methods cannot be performed for technological or ALARA reasons (e.g., container size, weight, shielding, dose rate). The reason for selection of this method is documented.

Method. A portable dose rate meter is used to determine the contact dose rate at six evenly distributed points on the exterior of the waste package. The six readings obtained are recorded and averaged. The average reading is compared with the container contact dose rate recorded on the transfer/shipment documentation.

Failure criteria. If the average dose rate observed during the dose rate profile examination differs from that recorded on the transfer/shipment documentation by more than 100 percent, the container fails.

\subsection{CHEMICAL SCREENING PARAMETERS}

The following methods are approved for use in performing chemical screening.

(1) Ignitability and/or headspace volatile organic compound screening:

Rationale: To determine the potential ignitability and the presence or absence of volatile organic compounds in waste, and to ensure personnel adequately are protected. This method is used when containers are opened for inspection. This method can be applied to any matrix.

Method: A sample of the headspace gases in a container is analyzed by one or more of the following types of portable instrumentation: organic vapor monitor, colorimetric gas sampling tubes, or a lower explosive level meter.

Tolerance: High organic vapor readings in matrices not documented as having volatile organic content constitute failure. 


\section{(2) Peroxide screen:}

Rationale: To determine the presence of organic peroxides in solvent wastes, to alert personnel to potential hazards and to confirm consistency with the transfer/shipment documentation. The test is sensitive to low parts per million ranges.

Method: A peroxide test strip is dampened with a pipette sample of liquid waste. Solids are tested by first wetting the test strip with water and contacting a small sample of the waste. A blue color change indicates a positive reaction. The color change can be compared with a chart on the packaging to determine an approximate organic peroxide concentration.

Tolerance: Peroxide concentrations greater than 20 parts per million in liquid waste constituents that are known organic peroxide formers not documented as having been stabilized constitutes failure.

(3) Paint filter liquids test:

Rationale: To verify the presence or absence of free liquid in solid or semisolid material.

Method: To a standard paint filter, 100 cubic centimeters or 100 grams of waste are added and allowed to settle for 5 minutes. Any liquid passing through the filter signifies failure of the test.

Tolerance: Failure of the test constitutes failure of the container. Small quantities of condensate trapped in inner plastic liner folds are acceptable.

(4) $\mathrm{pH}$ screen:

Rationale: To identify the $\mathrm{pH}$ and corrosive nature of an aqueous or solid waste and to confirm consistency with the transfer/shipment documentation.

Method: Full range $\mathrm{pH}$ paper is used for the initial screening. If the initial screen indicates a pH below 4 or above 10, a pH meter could be used, or a narrow range $\mathrm{pH}$ paper. Solids are mixed with an equal weight of water and the liquid portion of the solution is tested.

Tolerance: $\mathrm{pH}$ paper for this test has a sensitivity of $+/-1.0 \mathrm{pH}$ units. If the $\mathrm{pH}$ of a matrix appears to exceed regulatory limits $(<2.0$ or $>12.5)$ in waste not documented as being regulated for this property, the container fails the test.

(5) Oxidizer screen:

Rationale: To determine if a waste exhibits oxidizing properties to confirm consistency with the transfer/shipment documentation. This test can be applied to waste liquids, solids, and semisolids.

Method: Acidified potassium iodide (KI) test paper is applied to solid or liquid waste. A darkening of the paper is a positive indication.

Tolerance: This method is very sensitive to oxidizing properties. A positive indication in a waste that cannot be explained by documented constituents constitutes failure.

(6) Water reactivity screen: 
Rationale: To determine if the waste has the potential to vigorously react with water, form gases, or other reaction products. This information is used to confirm consistency with the transfer/shipment documentation.

Method: Water is added to a sample of solid or liquid waste. The solution is observed for evidence or fuming, bubbling, spattering, or temperature change. These reactions are considered to be positive evidence that the waste is water reactive.

Tolerance: A positive indication in a waste that cannot be explained by documented constituents constitutes a failure.

(7) Cyanide screen:

Rationale: To indicate if waste could release hydrogen cyanide upon acidification near $\mathrm{pH} 2$. This information is used to confirm consistency with the transfer/shipment documentation.

Method: To a test tube or watch dish containing approximately 2 milligrams of sample, an equal amount of freshly prepared ferrous ammonium citrate is added. 3 Normal hydrochloric acid is used to reduce the $\mathrm{pH}$ of the solution to near 2.0. A deep blue color indicates the presence of cyanide.

Tolerance: A positive indication in a waste that cannot be explained by documented constituents constitutes a failure.

(8) Sulfide screen:

Rationale: To indicate if the waste could release hydrogen sulfide upon acidification near $\mathrm{pH} 2$. This information is used to to confirm consistency with the transfer/shipment documentation.

Method: Approximately 2 milligrams of sample is added to a watch dish or test tube and enough 3 Normal hydrochloric acid is added to bring the $\mathrm{pH}$ down to near 2.0. A sulfide test strip is placed in the solution. If the test strip turns brown or silvery black, the presence of sulfides in the sample is indicated.

Tolerance: A positive indication in a waste that cannot be explained by documented constituents constitutes a failure.

\section{(9) HOC screen:}

Rationale: To indicate whether polychlorinated biphenyls (PCBs) or other chlorinated solvents are present in the waste. This information is used to confirm consistency with the transfer/shipment documentation, and to determine if the waste needs to be managed in accordance with the regulations prescribed in the Toxic Substance Control Act of 1976.

Methods: Field organic chlorine tests appropriate to the matrix, such as those offered by the Dexsil Corporation (e.g. Chlor-N-Oil, Chlor-N-Soil) are used. These screening tests are available with several detection limits. At a minimum, the 50 parts per million test is performed on oily matrices.

Tolerance: A positive indication of chlorinated organics in a waste not documented as having chlorinated organic content constitutes failure. 
HNF-5841

\section{$1 \quad 3.3$ OTHER ANALYSIS PARAMETERS}

2 Parameters needed to meet other waste characterization needs for waste managed at LLBG are identified in 3 Appendix A. 


\section{HNF-5841}

1

2

3

4

5

This page intentionally left blank. 


\subsection{SELECTING SAMPLING PROCESSES}

Specific sampling processes and techniques depend on both the nature of the material and the type of packaging. This section describes the sampling methodology used to obtain representative samples.

\subsection{SAMPLING STRATEGIES}

Table 4-l contains waste forms and sample equipment used to sample referenced waste. Sampling of these waste forms is performed in accordance with Table 4-1.

\subsection{SAMPLING METHODS}

The appropriate personnel are responsible for arranging all sampling and laboratory support for sample analysis. Samples are processed at one of several laboratories qualified to perform analysis of waste samples (refer to Section 5.0). Sampling methods are those described in WAC 173-303 110(2).

The basic sampling sequence is as follows:

- Obtain a unique sample number and complete the sample tag before sampling

- Obtain a precleaned sampler and sample bottles

- Attach sample label to sample bottles

- For sampling liquid waste, a sampler or pipette will be used to sample for two phase liquids. Homogeneous liquids in small containers will be poured into a sample bottle

- For sampling solid waste, a scoop, trier, or hand auger will be used to obtain a sample of the waste. For large containers of waste, composite several augers or scoops to ensure samples are representative

- Fill sample containers in the following sequence: volatile organics, semivolatile organics, metals, ignitability, $\mathrm{pH}$ (corrosivity)

- For solid waste, wipe the exterior surfaces of the sample bottles with a dry rag

- Attach sample labels to outer plastic bags

- Place samples in an appropriate receptacle for transfer to the laboratory

- Complete the chain-of-custody forms

- Seal and mark the receptacle in accordance with WAC 173-303-071(3)(1)

- Transfer receptacle to the analytical laboratory as appropriate to meet sample holding times

- Properly clean and decontaminate nondisposable sampling equipment or package for return to central sampling equipment decontamination area according to onsite requirements. 


\subsection{SELECTING SAMPLING EQUIPMENT}

Sampling equipment selection is detailed in Table 4-1. Waste sampling equipment is maintained and decontaminated as necessary by the LLBG operating organization.

\subsection{SAMPLE PRESERVATION}

Sample preservation follows SW-846 protocol or other approved sample preservation methods for waste in accordance with 62 FR 62079.

\subsection{ESTABLISHING QUALITY ASSURANCE/QUALITY CONTROL PROCEDURES FOR SAMPLING}

The sampling team ensures all samples are labeled with a unique identifier.

Sample collectors prepare a permanent log of sampling activities. Log entries include as appropriate: date of collection, time of collection, location, batch number, sample number, copy of the chain-of-custody form, sampling methodology, container description, waste matrix (liquid), description of generating process (e.g., decontamination activities), number and volume of samples, field observations, field measurements (e.g., $\mathrm{pH}$, percent lower explosive limit), laboratory destination and laboratory number, and signature. These logs entries are made by the appropriate personnel ${ }^{3}$ while the sampling is performed. The logs are permanent records of the TSD unit and must be retained in the Operating Record. If sampling is conducted in a posted radiological zone, the logbook entries could be made by a person who is outside the zone or by the sampler immediately after the sampling is completed. The sampling logs are retained in accordance with standard industrial practices. A chain-of-custody record accompanies samples at all times. The record contains a unique sample number for each sample, date and time of collection, sample type, sample location, methods of transfer, and signatures (or electronic equivalent, e.g., signature password) of the collector and all subsequent custodians.

During all sampling activities, strict compliance with applicable industrial hygiene and safety standards is mandatory. If sampling personnel accidentally contact waste material, decontamination of sampling personnel is performed immediately. Transportation of samples is performed in accordance with all applicable onsite and U.S. Department of Transportation requirements.

The following QA/QC elements are used by the LLBG operating organization to ensure sampling activities for designation purposes result in acceptable laboratory data:

- Representative sampling methods as defined by WAC 173-303-110(2), 40 CFR 261 Appendix I, and/or SW-846 Chapter 9

- Appropriate sample containers and equipment

- Samples numbered

3 'appropriate personnel' are defined as sampling personnel or a person directed by a sampler. 


\section{HNF-5841}

1

2

4

5

6

7

8

9

10

- Traceable labeling system

- Field QA/QC samples (applicable sampling and analysis plan)

- Equipment calibration (current as appropriate)

- Chain of custody. 


\section{HNF-5841}

1

2

3

4

This page intentionally left blank. 
Table 4-1. Low-Level Burial Ground Chemical Screening Sampling Equipment.

\begin{tabular}{|c|c|c|}
\hline \multirow{2}{*}{ Waste form } & \multicolumn{2}{|c|}{ Reference in SW-846 } \\
\hline & Waste type & Equipment* \\
\hline Liquids & Free-flowing liquids and slurries & $\begin{array}{l}\text { COLIWASA, SW-846, Chapter } 9 \text {, } \\
\text { glass thief or pipet }\end{array}$ \\
\hline Solidified liquids & Sludges & $\begin{array}{l}\text { Trier, SW-846, Chapter 9, scoops and } \\
\text { shovels }\end{array}$ \\
\hline Sludges & Sludges & $\begin{array}{l}\text { Trier, SW-846, Chapter 9, scoops and } \\
\text { shovels }\end{array}$ \\
\hline Soils & $\begin{array}{l}\text { Sand or packed powders and } \\
\text { granules }\end{array}$ & $\begin{array}{l}\text { Auger, SW-846, Chapter 9, scoops } \\
\text { and shovels }\end{array}$ \\
\hline Absorbents & Large-grained solids & $\begin{array}{l}\text { Large trier, SW-846, Chapter } 9 \text {, } \\
\text { scoops and shovels }\end{array}$ \\
\hline Wet absorbents & Moist powders or granules & $\begin{array}{l}\text { Trier, SW-846, Chapter 9, scoops and } \\
\text { shovels }\end{array}$ \\
\hline \multirow{4}{*}{ Process solids and salts } & Moist powders or granules & $\begin{array}{l}\text { Trier, SW-846, Chapter 9, scoops and } \\
\text { shovels }\end{array}$ \\
\hline & Dry powders or granules & $\begin{array}{l}\text { Thief, SW-846, Chapter 9, scoops and } \\
\text { shovels }\end{array}$ \\
\hline & $\begin{array}{l}\text { Sand or packed powders and } \\
\text { granules }\end{array}$ & $\begin{array}{l}\text { Auger, SW-846, Chapter 9, scoops } \\
\text { and shovels }\end{array}$ \\
\hline & Large-grained solids & $\begin{array}{l}\text { Large trier, SW-846, Chapter 9, } \\
\text { scoops and shovels }\end{array}$ \\
\hline \multirow{3}{*}{ Ion exchange resins } & Moist powders or granules & $\begin{array}{l}\text { Trier, SW-846, Chapter 9, scoops and } \\
\text { shovels }\end{array}$ \\
\hline & Dry powders or granules & $\begin{array}{l}\text { Thief, SW-846, Chapter 9, scoops and } \\
\text { shovels }\end{array}$ \\
\hline & $\begin{array}{l}\text { Sand or packed powders and } \\
\text { granules }\end{array}$ & $\begin{array}{l}\text { Auger, SW-846, Chapter 9, scoops } \\
\text { and shovels }\end{array}$ \\
\hline
\end{tabular}

COLIWASA = composite liquid waste sampler.

* other ASTM approved equipment could be used to collect samples. 


\section{HNF-5841}

1

2

3

4

This page intentionally left blank. 


\subsection{SAMPLING AND ANALYTICAL PROGRAM}

QC will be applied in implementing both sampling and analytical techniques. Specific performance standards for QA and QC methods for individual sampling and analysis activities are dynamic and are revised as warranted to reflect technological advances in available, appropriate techniques. These performance standards are described in policies maintained at LLBG and are available for review on request.

These sampling and analytical quality policies help ensure that the sample obtained provides precise and accurate analytical results for the waste being sampled. The analytical results are used by LLBG operating organization to decide whether or not to accept a particular waste. On acceptance, results are used to determine the appropriate method of treatment and storage and that incompatible waste is not combined inadvertently. Just as these analytical results are important, so is the quality of the sampling program.

\subsection{SAMPLING PROGRAM}

Sampling procedures for LLBG operations are described in Section 2.2.4. Selection of sample collection devices depends on the type of sample, the sample container, the sampling location, and the nature and distribution of regulated constituents in the waste. In general, the methodologies used correspond to those referenced by 40 CFR Part 261, Appendix I. The selection and use of the sample collection device are supervised or performed by qualified personnel.

Sampling equipment are constructed of materials that nonreactive with the waste being sampled. Materials such as glass, polyvinyl chloride plastic, aluminum, or stainless steel could be used. Care is taken in the selection and use of the sample collection device to prevent contamination of the sample and to ensure compatibility with the waste being sampled. Individual container samples that are related and compatible could be composited before analysis.

\subsection{ANALYTICAL PROGRAM}

A program of analytical QC practices and methods has been developed on the Hanford Site to ensure that precision and accuracy are maintained throughout the laboratories. Good laboratory practices that encompass sampling, sample handling, housekeeping, and safety are maintained at onsite laboratories. 
HNF-5841

This page intentionally left blank. 


\subsection{SELECTING WASTE RE-EVALUATION FREQUENCIES}

2 The re-evaluation (repeat and review) frequency to review profile information is yearly, or more often if the 3 waste generation process changes.

4

5

6

7

8

9

10

11

12

13

14

15

16

17

The LLBG operating organization re-evaluates a waste profile if the following occurs.

- A generator notifies the LLBG operating organization that the generating process has changed.

- Inspection or analysis indicates that the waste received at LLBG does not match the profile and/or transfer/shipment documentation.

When a waste profile is re-evaluated, the LLBG operating organization could request the generator to do one of the following:

- Verify the current waste profile is accurate

- Supply a new waste profile

- Submit a sample for parameter analysis. 


\section{HNF-5841}

This page intentionally left blank. 


\subsection{SPECIAL PROCEDURAL REQUIREMENTS}

This section discusses any special process requirements for receiving mixed waste at the LLBG.

\subsection{PROCEDURES FOR RECEIVING WASTE GENERATED ONSITE}

In general, mixed waste received from onsite generator units is managed in the same manner as waste received from offsite generators. Differences include, but are not limited to, the following: (1) physical and chemical screening frequencies for verification (minimum percentages of 5 percent for waste from onsite generating units and 10 percent for waste from offsite generators (note that chemical screening frequency depends on the physical screening frequency), (2) transfer/shipment documentation (Uniform Hazardous Waste Manifest are used for waste from offsite generators and waste tracking forms are used for waste from onsite generating units), and (3) LDR documentation requirements (notification for waste from offsite generators and the information contained in the notice for waste from onsite generating units).

\subsection{PROCEDURES FOR RECEIVING WASTE GENERATED OFFSITE}

Mixed waste received from offsite is handled in the same manner as mixed waste received from onsite, with the exception of those items described in Section 7.1 and defueled reactor compartments disposed in trench 94 of the 218-E-12B Burial Ground, which are transported directly from the generator to trench 94 .

\subsection{PROCEDURES FOR IGNITABLE, REACTIVE, AND INCOMPATIBLE WASTE}

The LLBG do not accept ignitable, reactive, or incompatible waste (refer to Section 1.2). The LLBG operating organization ensures that ignitable, reactive, or incompatible waste is not accepted at the LLBG in the following manner.

- Pre-shipment review and chemical screening ensures ignitable and reactive waste is not accepted.

- Pre-shipment review ensures waste incompatible with the liner is not accepted in the lined trenches.

\subsection{PROVISIONS FOR COMPLYING WITH FEDERAL AND STATE LAND DISPOSAL RESTRICTION REQUIREMENTS}

33 Sections 1.1.4.1.2 and 2.1.2 describe compliance with federal and state LDR requirements. 
HNF-5841

This page intentionally left blank.

000302.0901 
HNF-5841

\subsection{RECORDKEEPING}

2 Recordkeeping requirements that are applicable to this WAP are described in Chapter 12.0, Table 12-1, of

3 the Hanford Facility Dangerous Waste Permit Application, General Information Portion (DOE/RL-91-28)

4 and within this WAP. 


\section{HNF-5841}

1

2

3

4

5

This page intentionally left blank. 


\subsection{REFERENCES}

2 DOE/RL-88-21, Hanford Facility Dangerous Waste Part A Permit Application, U.S. Department of 3 Energy, Richland Operations Office, Richland, Washington.

4

DOE/RL-91-28, Hanford Facility Dangerous Waste Permit Application, General Information Portion, U.S. Department of Energy, Richland Operations Office, Richland, Washington, revised periodically.

SW-846, Test Methods for Evaluating Solid Waste, Physical/Chemical Methods, latest edition, U.S. Environmental Protection Agency, Washington, D.C.

10

EPA-600/4-7-020, Methods for Chemical Analysis of Water and Wastes, U.S. Environmental Protection Agency, Environmental Monitoring and Support Laboratory, Cincinnati, Ohio.

62 FR 62079, Mixed Waste Testing Guidance, November 20, 1997.

15 


\section{HNF-5841}

This page intentionally left blank. 
HNF-5841

1

APPENDIX A

2

3

4

5

ANALYTICAL PARAMETRES, METHODS, AND RATIONALE FOR WASTE RECEIVED AT LOW-LEVEL BURIAL GROUNDS 


\section{HNF-5841}

This page intentionally left blank. 
HNF-5841

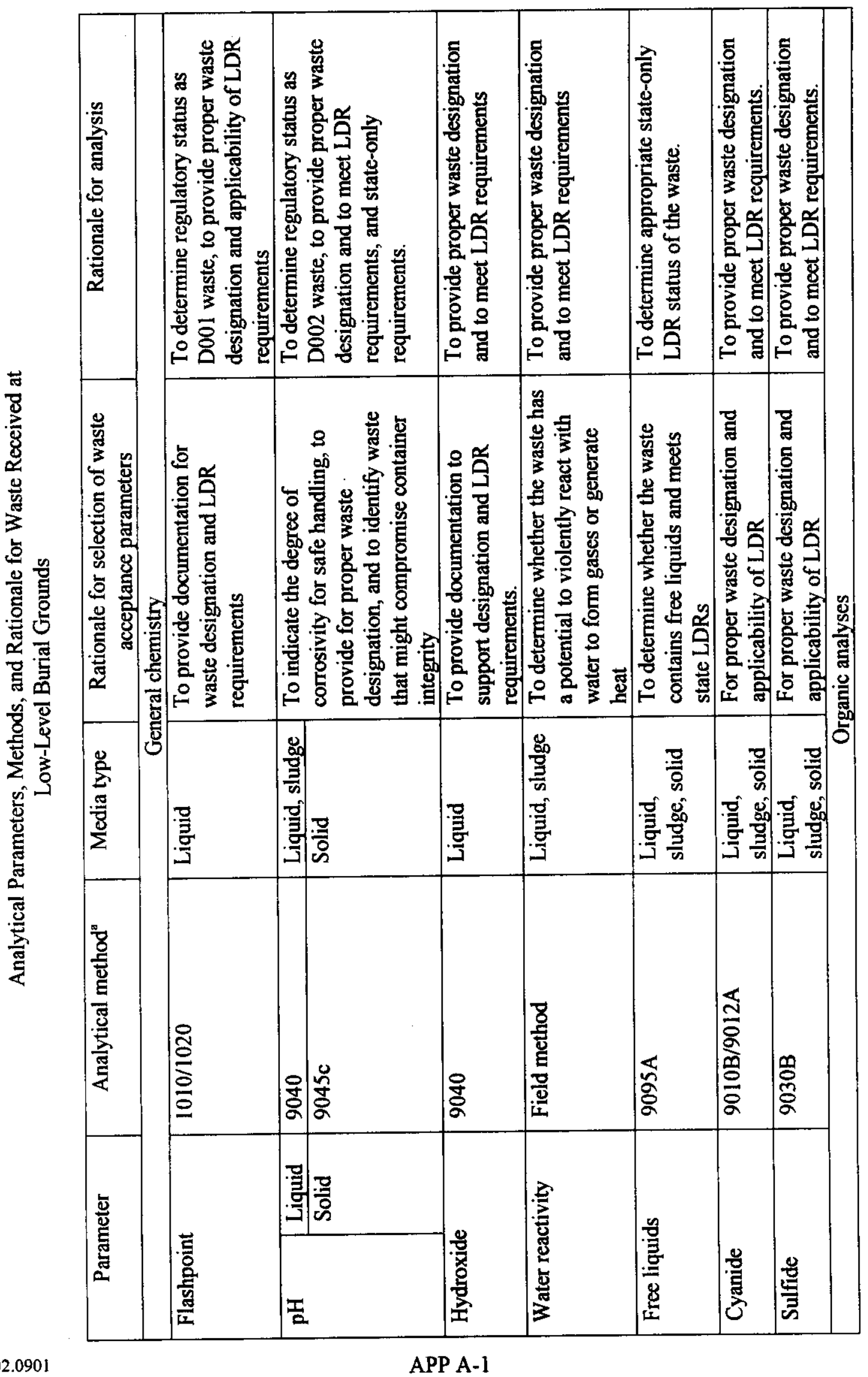


HNF-5841

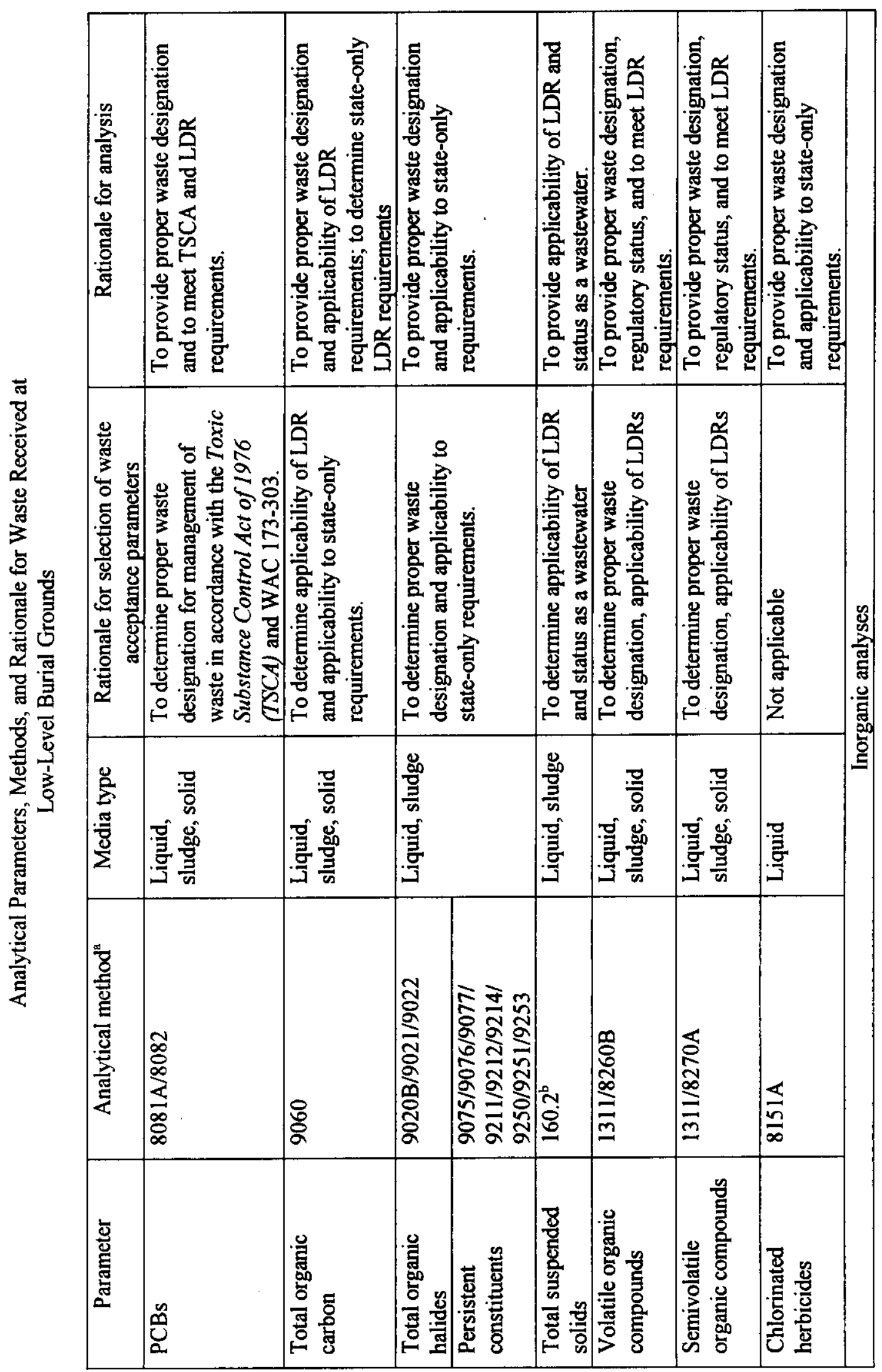


HNF-5841

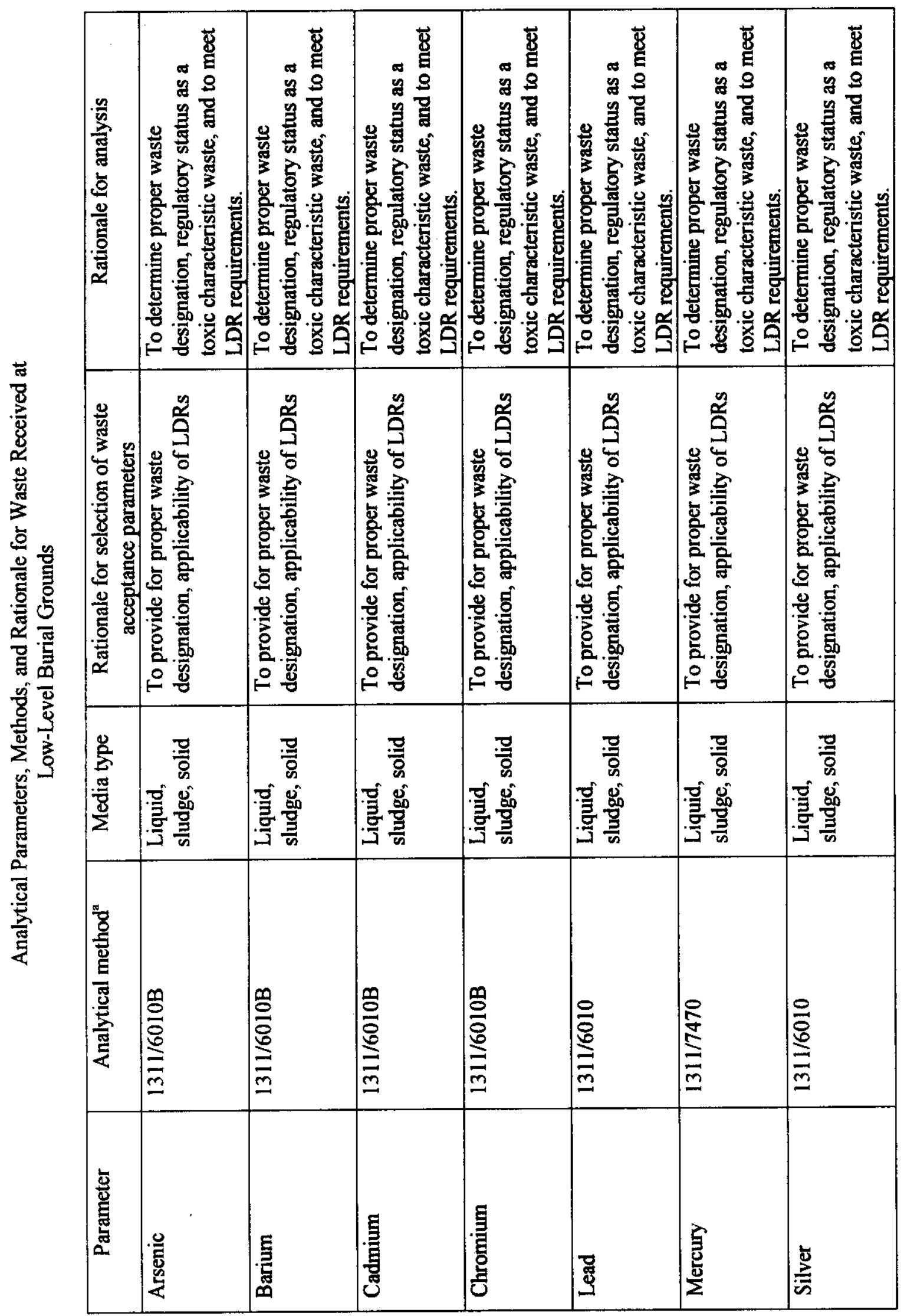


HNF-5841

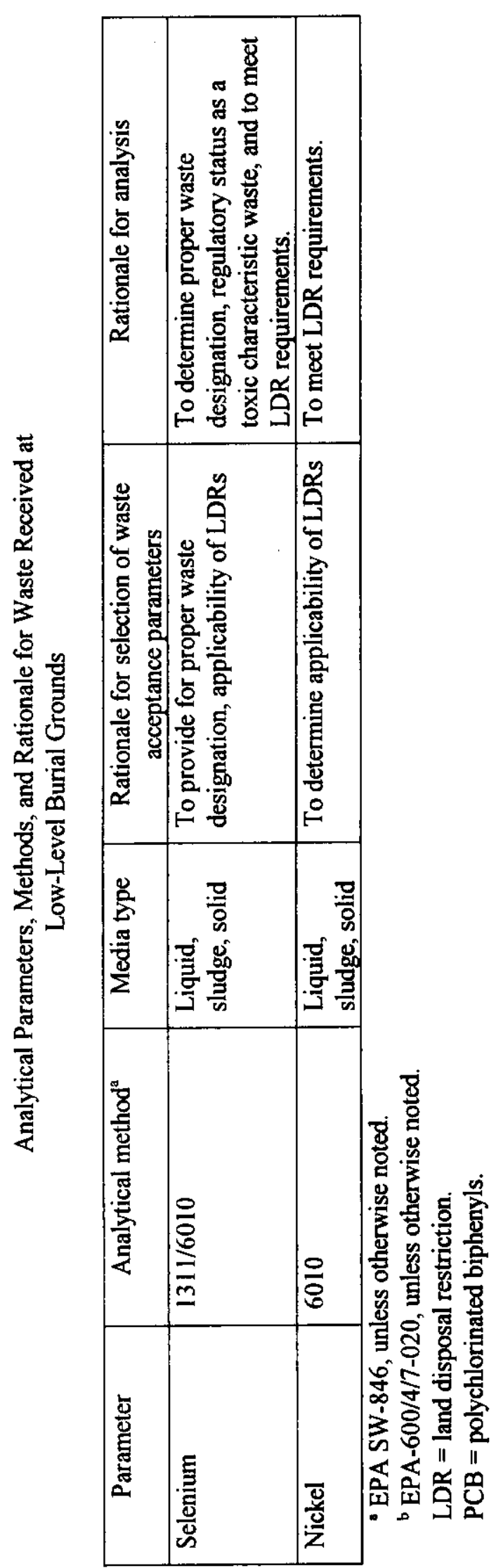

000302.0901 


\section{DISTRIBUTION}

MSIN

Fluor Hanford

R. E. Bolls

T3-05

J. B. Buckley, Jr.

T4-05

M. D. Ellefson

T3-05

C. K. Girres

T3-01

R. D. Greenwell

T3-05

J. O. Hanley

T4-05

C. A. McNaughton

T4-06

D. A. Pratt

T4-03

J. R. Rosser

T4-03

D. G. Saueressig

T4-04

G. C. Triner

T3-05

J. F. Williams Jr.

G1-30

Lockheed Martin Services, Inc.

Central Files

B1-07

DPC

H6-08 
HNF-5841

This page intentionally left blank. 